\title{
Recent Progress in Cleaner Preservation of Raw Hides and Skins
}

\author{
Jiacheng $\mathrm{Wu}^{\mathrm{a}, \mathrm{b}}$, Li Zhao ${ }^{\mathrm{a}, \mathrm{b}}$, Xiong Liu ${ }^{\mathrm{a}, \mathrm{b}}$, Wuyong Chen ${ }^{\mathrm{a}, \mathrm{b}}$, Haibin $\mathrm{Gu}^{\mathrm{a}, \mathrm{b} \mathbf{}}$ \\ ${ }^{\text {a }}$ Key Laboratory of Leather Chemistry and Engineering of Ministry of Education, Sichuan \\ University, Chengdu 610065, China \\ ${ }^{\mathrm{b}}$ National Engineering Laboratory for Clean Technology of Leather Manufacture, Sichuan \\ University, Chengdu 610065, China.
}

\begin{abstract}
The raw hides and skins are flayed from animals and further processed into leathers. As the main constituent of raw skins and hides is protein, these materials are highly susceptible to bacterial action. Therefore, adequate preservation of hides and skins is crucial in slaughterhouses and tanneries. Preservation using salt remains the most popular curing technique worldwide due to its ease, cost-effectiveness and the quality of the finished leather produced. The use of salt (approximately $40-50 \%$ on raw hides/skins weight) enhances the pollution load of tannery effluent, however, which becomes highly contaminated with increased total dissolved solids (TDS) and chlorides $\left(\mathrm{Cl}^{-}\right)$. To overcome this hurdle, researchers are constantly searching for alternative preservation techniques which are either totally void of salt or use only a small amount of salt. Based on the literatures published mainly in the past decade, this review systematically and comprehensively summarizes current status and development trend about the cleaner preservation methods used in curing and soaking processes. The discussed salt-less curing methods contain $\mathrm{NaCl}+\mathrm{EDTA}, \mathrm{NaCl}+$ silica gel, $\mathrm{NaCl}+$ sodium meta-bisulphite and $\mathrm{NaCl}+$ boric acid, while the illustrated alternatives used in salt-free curing methods include potassium chloride $(\mathrm{KCl})$, sodium sulphate $\left(\mathrm{Na}_{2} \mathrm{SO}_{4}\right)$, silicate and peracetic acid. Emphasis is put on natural preservatives (paste plant formulations, essential oils, chlorophyll and bacteriocins), polyethylene glycol (PEG), ozone and physical preservative methods containing electric current, chilling and vacuum. Furthermore, several proposals are addressed for the development of eco-friendly and efficient preservation methods for hides and skins.
\end{abstract}

Keywords: Cleaner preservation, hides and skins, salt-less, salt-free, natural preservatives.

\section{Introduction}

Raw hides and skins, the most valuable byproduct of meat industry, are normally converted into leathers. Leather-making industry is an age-old industry that has been serving the society as an important consumer industry. It provides the unique raw materials used to

\footnotetext{
${ }^{1}$ Corresponding author

E-mail: guhaibinkong@126.com (Haibin Gu)
} 
manufacture a wide range of consumer goods such as garments, shoes, bags and so on. However, tannery industry has been categorized as one of the highly polluting industries due to its adverse influence on the environment (Kanagaraj et al., 2002, 2015; Dixit et al., 2015). Using the salt-cured raw hides and skins as the manufactured object, leather-processing typically involves a variety of processing steps that can be divided into four stages (Covington, 2011). The first stage is called preparation process that contains mainly soaking, degreasing, dehairing, liming, deliming and bating, and its fundamental purpose is to remove the unnecessary substances such as dirt, hair, grease and nonstructural proteins, and to open up collagenous fibers. The second stage is tanning process in which hides and skins are subjected to acid treatment (pickling), and then tanned by using metal salts (chromium (III) salt, for example) or vegetable tannins. The tanned hides and skins are named as leathers which are fundamentally different from their original materials. The third stage is also carried out in water environment where the dyeing, retanning and fatliquoring are often conducted to give leather colors, softness and some special properties. Finally, the leather is finished on the surface and mechanically treated to endow it with fashionable appearance and style. As shown in Figure 1, various chemicals that are used during these processes are not fully absorbed by leathers leaving huge amount of pollution load through effluent streams. It is approximated that over $600 \mathrm{~kg}$ of waste is generated and $30-35 \mathrm{~m}^{3}$ of water is used for every ton of wet-salted hide, which results in 200-300 kg of leather (Ozgunay et al., 2007).

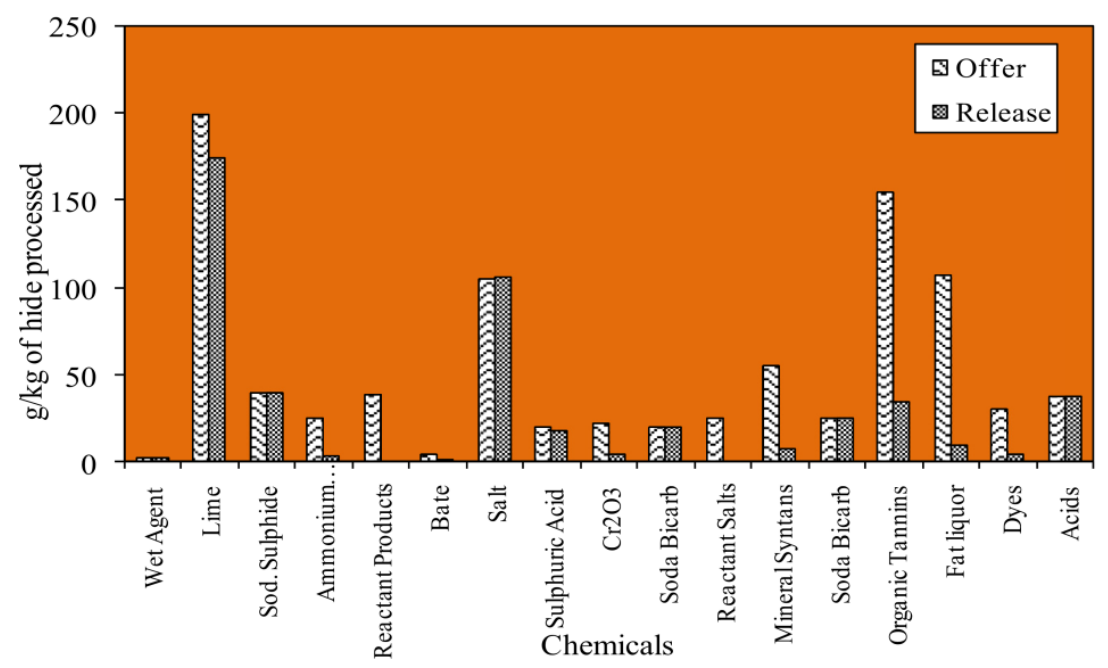

Figure 1 Representative chemicals used in leather processing operations (Kanagaraj et al., 2015).

Especially, salt used mainly in the curing of hides and skins, soaking, pickling and chrome tanning operations generates huge amounts of pollution in terms of total dissolved solids (TDS) and chlorides in the resulting effluent during leather-making process. Thereinto, the salt-curing accounts for about $40 \%$ of chlorides and $55 \%$ of TDS, respectively, in the entire leather-processing operations (Yu, 1999; Peng et al., 2014). Unfortunately, there is still no efficient and cost-effective technology available for treatment of the effluent containing such high concentration of neutral salt. To date, the salt-based curing method has been still occupying the dominant position in the preservation of hides and skins although the need for an alternative, 'eco-acceptable' curing system is widely recognized. Preservation of skins and 
hides by salt is based on the application of sodium chloride $(\mathrm{NaCl})$ at a concentration of 40-50\%, and its dual functions, namely dehydrating ability and bacteriostatic effect, are used profitably in this method (Bailey, 2003). The low-cost and low-tech properties are possibly the main reasons that this method is widely applied in the long-term preservation of hides. Even so, many weaknesses have been noticed in the salt curing (Bailey, 2003). For example, the destructive role of bacteria (Cadirci et al., 2010; Berber and Birbir, 2010a; Aslan and Birbir, 2011b, 2012; Lama et al., 2012, 2013; Ulusoy and Birbir, 2015), especially halophilic bacteria (Bailey and Birbir, 1996a; Shede et al., 2008; Berber et al., 2010c; Bilgi et al., 2015; Akpolat et al., 2015; Caglayan et al., 2015) has become more realistically appraised in the hide curing and storage process. Halophilic bacteria contain special lipases and proteases that can potentially digest substances in salt-cured hides, and it can result in the "red heat", one of the most common disadvantages of raw hides (Akpolat et al., 2015). The red color associated with these organisms is due to a pigment produced by these bacteria. When this red coloration is found on salt-cured hides, it clearly shows that these organisms are present on the hides. Another serious problem related to hide quality and curing is caused by a delay in cure that allows sufficient growth of microorganisms on the hide to damage the grain (Bailey, 2003; Aslan and Birbir, 2011a). No matter how well a hide is cured by salt, damage occurring before cure cannot be fixed, which is more common in hides that have to be collected from small abattoirs and taken to a central curing facility. Other problem of salt curing is transportation difficulties, and of course, the most serious and disputed issue is the negative impact on the environment as it burdens the environment with large amounts of the TDS and chlorides. The electrolytes discharged by the use of salt by the tanning industry led to the aggravation on the quality of soil and ground water, and this phenomenon get worse now more than ever before.

For these reasons, a close attention has been paid to salt curing itself in order to decrease the amount of salt used by the technology optimization and modification (Aslan and Birbir, 2011a; Eduard et al., 2008; Vijayalakshmi et al., 2009b; Barinova et al., 2009; Balada et al., 2009) as it is still the most widespread method of long-term raw hide preservation, and eco-friendly alternatives of salt curing have been intensively investigated simultaneously. Since the late 1970s, a number of alternative methods to conventional salt-curing have been investigated or adopted by industry to varying degrees in order to reduce dependence on salting. Based mainly on the past decades literatures, this review will provide comprehensive progress on the salt-less and salt-free preservation methods and emphasis will be put on the natural plant preservatives, chemical substances with antimicrobial and non-polluting properties, and advanced physical preservative technologies for the purpose of long and short-term preservation for raw hides and skins.

\section{Salt-less methods}

\section{1. $\mathrm{NaCl}+$ EDTA}

A powder biocide composition called Liricure was developed by Russell et al. (1997, 1998) in South Africa to be applied to the preservation of hides and skins. This low salt antiseptic delivery system is a mixture of $25 \%$ tetra-sodium ethylene diamine tetra-acetic acid 
(EDTA), 40\% common salt and 35\% medium coarse sawdust (pine), and can be directly applied to the flesh surface of hides and skins. A substantial storage period (6 weeks in field trials) was found to be possible by distributing this powder on the moist flesh surface (approx. $200 \mathrm{~g}$ per sheepskin or $3 \mathrm{~kg}$ per cattle hide, for example), followed by folding flesh-to-flesh ("saddle-stacked") to maintain close contact with the applied preservative composition. Finished leathers were manufactured from the sheepskins and cattle hides after the storage period of 12 months, and their physical properties were reported to be comparable with that from salt cured system. Though EDTA is not basically regarded as a biocidal agent, its efficacy in the present application seems to derive from complexing and inactivation of metals in enzyme active sites, hence inhibiting bacterial growth and proliferation (Russell et al., 1997). And the inhibitory effect of the Liricure method appeared to be resulted also from the initial high antiseptic concentration into the surface moisture of skin, reduction in skin moisture and its water activity and shifts in skin surface $\mathrm{pH}$. Whatever, the Liricure method, registered as a joint (LIRI Technologies/Meat Board) South African Patent (SA Patent No. 95/0559), offers possibility of salt reduction (20\% or so) in local short-term rawstock transportation and holding under warm conditions without damage to leather quality, although the contained EDTA may cause difficulties in precipitating chromium compounds in effluent treatment (Russell et al., 1997).

\section{2. $\mathrm{NaCl}+$ silica gel}

A cleaner preservation technique using inert compound silica gel has been proposed by Kanagaraj et al. $(2000,2001)$ over conventional salt curing method. The used silica gel is prepared by mixing sodium meta-silicate and hydrochloric acid at $\mathrm{pH}$ of 5.5 and followed by spray drying. The recommended less-salt method for preservation uses $5 \%$ silica gel and 5\% salt with or without $0.1 \%$ PCMC ( $p$-chlorometacresol). In this system, silica gel absorbs the moisture and salt diffuses inner the skin matrix which adds to the dehydration and inhibits bacterial growth (Kanagaraj et al., 2000). As shown in Figure 2, the moisture content of all the tested less-salt preserved stock after 24 hours is lower than the critical moisture content of $50 \%$, which indicates the less chance of putrefaction to the stock, and after two weeks, this index is dropped to $33-35 \%$ versus $30-32 \%$ of the corresponding salt cured stock. The rate of decrease of moisture in the experiment is in analogous to that of the salt control. The curing efficacy of this new method was further assessed and confirmed by various parameters including bacteria counting, moisture content using NMR micro-imaging technique, total extractable nitrogen, hydrothermal stability of skin, scanning electron microscopic (SEM), physical strength properties of processed leather and pollution load generated in leather processing. All the results indicate that this method is as efficient as conventional salt curing and cannot pose any problem in soaking or in the leather manufacturing process and the corresponding leather quality is on a par with that obtained from conventionally salt cured stock. More importantly, the pollution load was reduced at the maximum level up to $70-75 \%$ for TDS and $80-85 \%$ for chlorides. Thus, this method appears to have environmental advantage over the conventional method, and can be an effective alternative. 


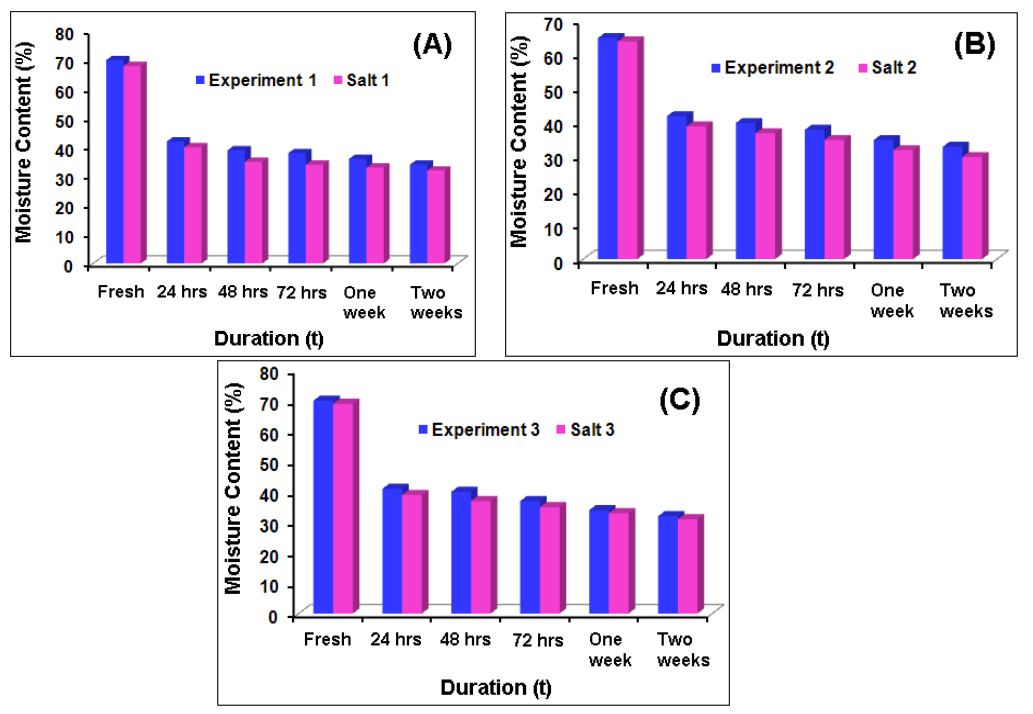

Figure 2 Moisture content for preserved goat skins (A and B) and buffalo hides (C) (Kanagaraj et al., 2000). Experiment 1: 5\% silica gel $+5 \%$ salt $+0.1 \%$ PCMC for goat skin; Experiment 2: $5 \%$ silica gel $+5 \%$ salt for goat skin; Experiment 3: 5\% silica gel $+5 \%$ salt + 0.1\% PCMC for buffalo hide; Salt 1-3: $40 \%$ salt.

\section{3 $\mathrm{NaCl}+$ sodium meta-bisulphite (SMBS)}

New preservation systems by using SMBS were developed by Kanagaraj et al. (2005a). The reported the salt-less (5\% $\mathrm{NaCl}$ with $0.5 \% \mathrm{SMBS})$ and salt-free (1\% SMBS only) curing systems can provide effective preservation for raw goat skins. Using the conventional $50 \%$ $\mathrm{NaCl}$ method as control, the two systems are optimized by evaluating of bacterial control, physical, biochemical and thermal characteristics of the preserved skin, the mechanical properties of the processed leathers, and the corresponding pollution load. As shown in Figure $3 \mathrm{~A}$, bacterial count is comparatively lower than in the salt cured skin, which reveals that skins are preserved in a better manner compared to the salt cured skin, and the results of hydrothermal stability (Figure 3B) also confirmed this point. The pollution profile (Figure 3C) of the preserved skin indicated the reduction of TDS and chlorides levels by about 15-20 times over the conventional salt-cured skin. Furthermore, these new curing agents, particularly the SMBS (1-1.5\%, w/w), could be used even at temperatures ranging from 35 to $40{ }^{\circ} \mathrm{C}$ without affecting the quality of skins.
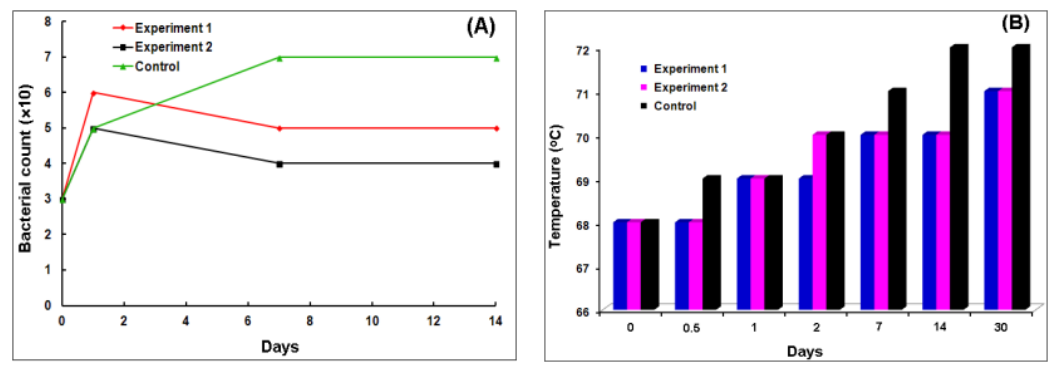


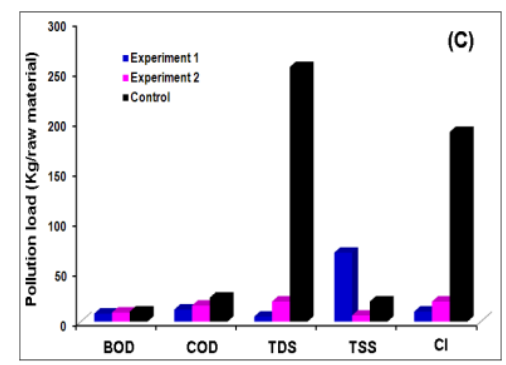

Figure 3 Bacterial count (A) of CFU/g and shrinkage temperatures (B) of the preserved skins, and pollution load $(\mathrm{C})$ generated in the soaking process. ${ }^{31}$ Experiment 1: $1 \%$ SMBS; Experiment 2: $5 \% \mathrm{NaCl}+0.5 \%$ SMBS; Control: $50 \% \mathrm{NaCl}$.

\section{4 $\mathrm{NaCl}+$ boric acid $(\mathrm{BA})$}

BA has bactericidal properties, tends to absorb moisture from the clearance between the fibers. The ability to absorb moisture from the inner layer to the surface and contribution to evaporation essentially helps to reduce the moisture level of the skins (Kanagaraj et al., 2005b). Salt-free and less-salt preservation systems based on BA were researched and evaluated at ambient temperature of $30-35^{\circ} \mathrm{C}$ as the alternative preservation methods (Kanagaraj et al., 2005b; Birbir et al., 2013a). It was found that the two optimized formulas, namely $5 \% \mathrm{BA}$ and $2 \% \mathrm{BA}+5 \% \mathrm{NaCl}$, exhibited comparable preservative effect to the conventional $40 \% \mathrm{NaCl}$ preservation system. The preserved raw goat skins showed no hair loosening or putrefaction odour, indicating absence of bacterial action. Furthermore, from SEM views of the preserved skins (Figure 4), it can be seen that there was no main distinction in the fiber structure and fiber orientation between the experimental and control samples (Kanagaraj et al., 2005b). Although the use of the BA based systems is more expensive than the conventional curing system, they can result in more than $80 \%$ reduction in chlorides and TDS in the effluents (Table 1). Since the new preservation systems do not require any complex new skills or apparatuses, they have a great potential to turn into feasible alternatives for the salt-curing system (Kanagaraj et al., 2005b). Although BA does not pose any serious health or safety problems on usage, its use for curing has recently come under effluent restriction in some countries containing Australia.
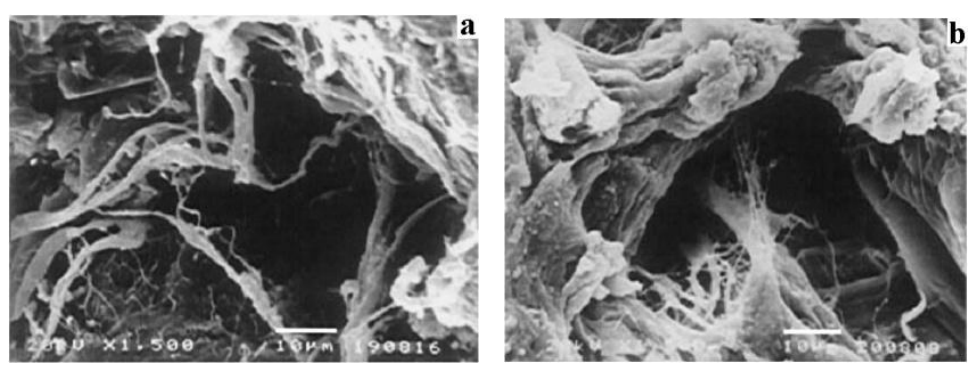

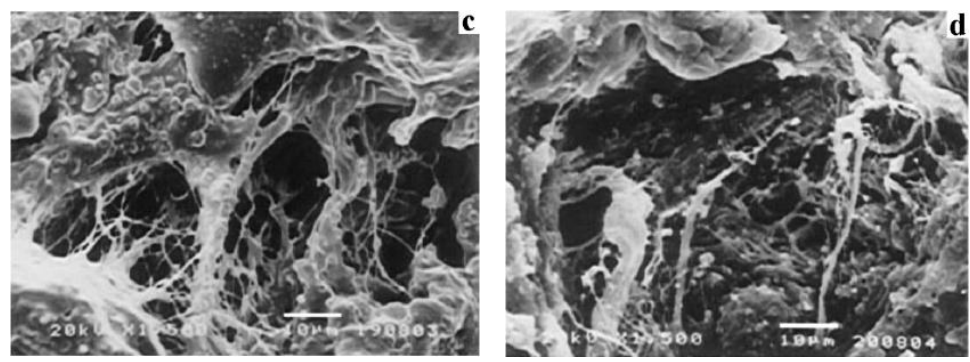

Figure 4 SEM images of the goat skins preserved with $5 \% \mathrm{BA}$ (a), $2 \% \mathrm{BA}+5 \% \mathrm{NaCl}$ (c), and $40 \% \mathrm{NaCl}$ as controls (b, d) (Kanagaraj et al., 2005b).

Table 1 Pollution load generated in the soaking process (Kanagaraj et al., 2005b).

\begin{tabular}{|c|c|c|c|}
\hline \multirow{2}{*}{ Parameters } & \multicolumn{3}{|c|}{ Pollution load generated $(\mathrm{g} / \mathrm{kg}$ of raw material) } \\
\cline { 2 - 4 } & $5 \% \mathrm{BA}$ & $2 \% \mathrm{BA}+5 \% \mathrm{NaCl}$ & Control $(40 \% \mathrm{NaCl})$ \\
\hline BOD & $7 \pm 0.5$ & $9 \pm 1$ & $9.5 \pm 1$ \\
\hline COD & $12 \pm 2$ & $17 \pm 1$ & $26 \pm 1$ \\
\hline TDS & $30 \pm 2$ & $45 \pm 2$ & $264 \pm 5$ \\
\hline TSS & $8 \pm 1$ & $10 \pm 0.5$ & $21 \pm 1$ \\
\hline Cl & $21 \pm 2$ & $22 \pm 1$ & $195 \pm 5$ \\
\hline
\end{tabular}

Values given are mean value of two determinations

\section{Salt-free curing methods}

\section{1. $\mathrm{KCl}$}

Potassium chloride $(\mathrm{KCl})$ has similar physical and chemical properties to $\mathrm{NaCl}$, but is very much different in one respect. While $\mathrm{NaCl}$ has negative effects on the growth of plants when applied to the soil, $\mathrm{KCl}$ is a fertilizer that encourages plant growth and do not result in the environment problems that are associated with saturated brine. It is the similar properties of the two salts that allow skins and hides to be cured with $\mathrm{KCl}$ in the same way as $\mathrm{NaCl}$. Bailey et al. (1994, 1995, 1996b) proved that $\mathrm{KCl}$ can be substituted for $\mathrm{NaCl}$ to produce brine cured hides. It can be done in paddles, raceways, processors or salt packs and in most respects will require almost no change in current brine curing facilities. They reported experimentally and commercially curing cattle hides, calfskins and pigskins with $\mathrm{KCl}$. The overall results suggest virtually no difference between the quality of hides and skins produced by this curing method compared to traditional curing with $\mathrm{NaCl}$. However, at the same time their research was reported the higher cost of $\mathrm{KCl}$ and the limited pressure on salt in packing house effluents precluded the use of this material for curing. Furthermore, the decreasing solubility of $\mathrm{KCl}$ as the temperature is lowered may have to be considered by hide processors in cold climates. The temperature of brine raceways will have to be maintained above $65{ }^{\circ} \mathrm{F}$. If the concentration of soluble $\mathrm{KCl}$ in the raceway falls below $4.25 \mathrm{M}$, the amount taken up by the hide may not be high enough to achieve the desired preservation. The option to use $\mathrm{KCl}$ as a fertilizer will also depend on the location of the curing operation. 


\section{2. $\mathrm{Na}_{2} \mathrm{SO}_{4}$}

To reduce the amount of TDS and chloride ion $\left(\mathrm{Cl}^{-}\right)$in the final effluent, sodium sulphate $\left(\mathrm{Na}_{2} \mathrm{SO}_{4}\right)$, which have similar properties to $\mathrm{NaCl}$ but no $\mathrm{Cl}^{-}$in its formulation, was investigated by Vankar et al. (2006, 2009a, 2009b) as curing agent alone and in combinations with $\mathrm{NaCl}$ for the preservation of goat skins and buffalo hides. The tested three $\mathrm{Na}_{2} \mathrm{SO}_{4}$-based curing systems contain $\mathrm{Na}_{2} \mathrm{SO}_{4}$ only, 90:10 and 80:20 $\left(\mathrm{Na}_{2} \mathrm{SO}_{4}: \mathrm{NaCl}\right)$ in the preservation of buffalo hides, and the amount utilized in curing was only one-fifth of $\mathrm{NaCl}$ in conventional salt-curing system. The treated hides were kept for 21 days at ambient temperature of 30-35 ${ }^{\circ}$ C. Efficiency of curing was systematically assessed by analyzing moisture content, total extractable nitrogen content and bacterial colony count in treated hides. Results indicated that $\mathrm{Na}_{2} \mathrm{SO}_{4}$ based formula showed better efficacy than the control. Moreover, there is massive reduction in the values of TDS and $\mathrm{Cl}^{-}$compared to the control salt mediated preservation (Figure 5). SEM analysis (Figure 6) further proved the uttered utility and compatibility of $\mathrm{Na}_{2} \mathrm{SO}_{4}$ as curing agent because it enhances bundling and striation of fibers which is supposed as prerequisite requirement for tannery acceptance (Vankar and Dwivedi, 2009b). Thus it can be concluded that $\mathrm{Na}_{2} \mathrm{SO}_{4}$ can easily replace $\mathrm{NaCl}$ for the short-term preservation of hides and skins as it is fortunately a commonly available chemical and can be used as a smart alternative in hide preservation technology.

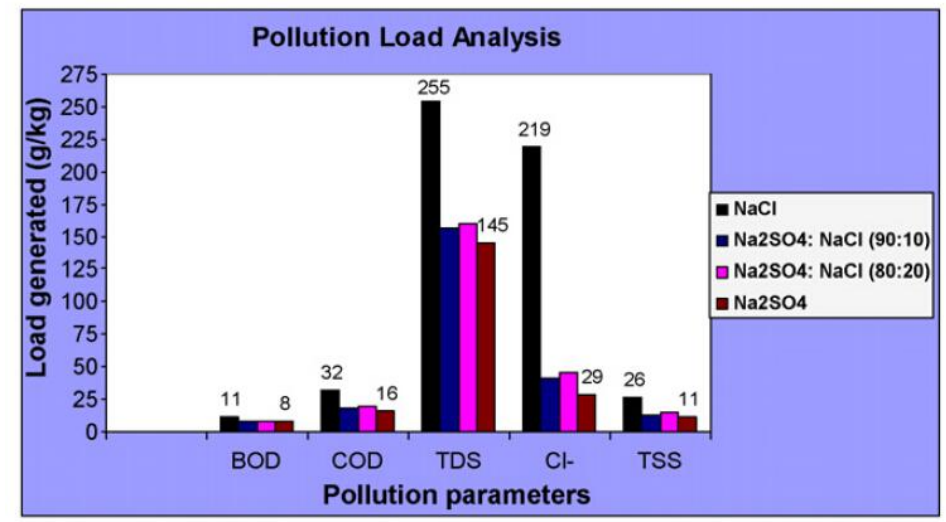

Figure 5 Pollution load analysis with experimental $\mathrm{Na}_{2} \mathrm{SO}_{4}$-based formulas and $\mathrm{NaCl}$ (Vankar and Dwivedi, 2009b).

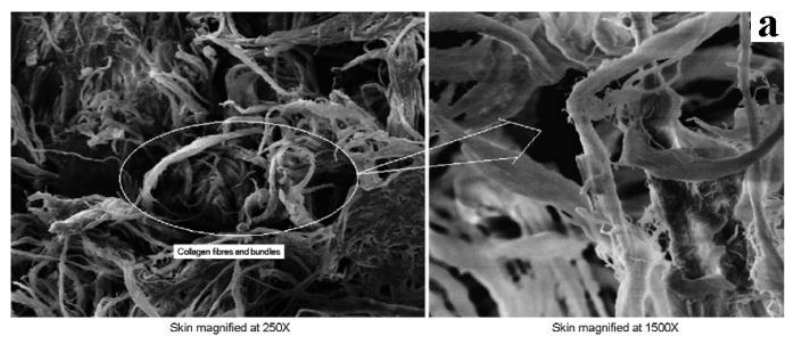




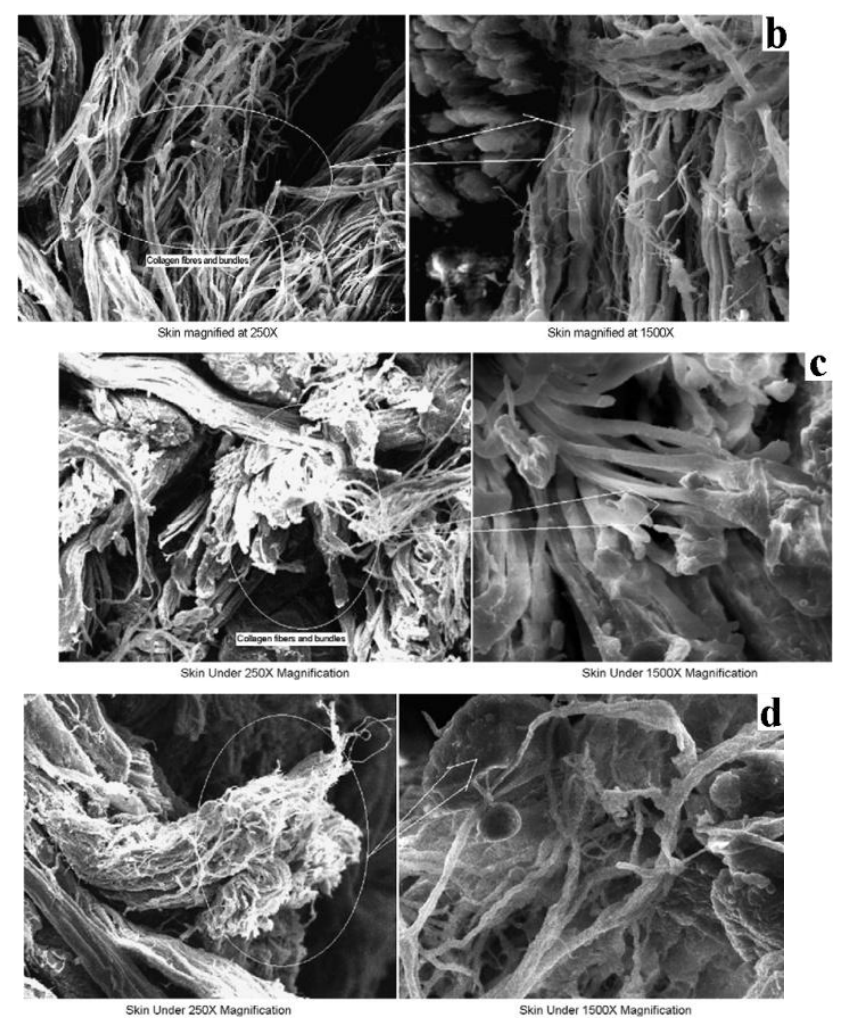

Figure 6 SEM images of hides treated with $\mathrm{NaCl}$ (a), $\mathrm{Na}_{2} \mathrm{SO}_{4}: \mathrm{NaCl}$ (90:10) (b), $\mathrm{Na}_{2} \mathrm{SO}_{4}: \mathrm{NaCl}$ (80:20) (c) and $\mathrm{Na}_{2} \mathrm{SO}_{4}$ (d) (Vankar and Dwivedi, 2009b).

\subsection{Silicate}

Munz (2007) developed new raw hide curing methods in which the common salt was replaced by the neutralized alkali silicates that were either applied as powder or by drum penetration. With the help of partners from Austria, Germany, UK, India and Bangladesh, the developed drum and powder methods have been implemented up to semi-technical scale into industry. In the drum method, firstly, skins and hides are soaked in sodium silicate solutions (float relation 100-150\%) containing 5-30\% sodium silicate. 2-5 hours later, the liquor is discharged, and after re-floating, the hides and skins are neutralized with citric acid to acid $\mathrm{pH}$ (5.0-5.5) and horsed for dehydration (Munz, 2007). These treated skins and hides can be stored for many months. Although these dried hides and skins resemble parchment (Figure 7a), after re-soaking they can be transformed into quality leather. For powder method, formic and sulphuric acid were used to neutralize the commercial sodium silicate solutions, then washed to remove neutral salts, dried and ground (Munz, 2007). The obtained white fine powder was applied in the same way as $\mathrm{NaCl}$ curing. Compared with $\mathrm{NaCl}$ curing, only about half the number of neutralized silicate powder (20-25\% wt in comparison with $40 \%$ salt) results in unexceptionable curing (Figure 7b) (Munz, 2007). 

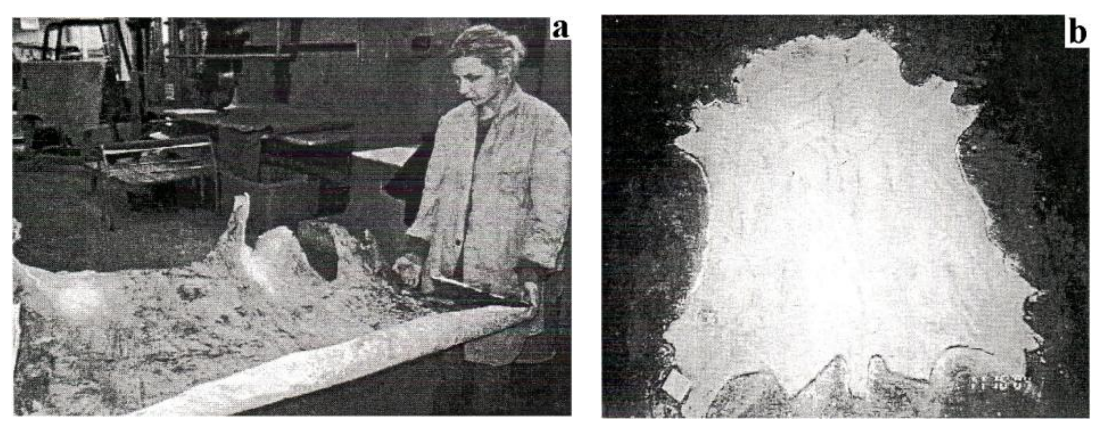

Figure 7 Silicate-cured bovine hide (a) by drum method and goat skin (b) by powder method (Munz, 2007).

Whether the application is the drum or powder method, strong dewatering occurred. Silicate cured hides and skins merely contain about $10-15 \%$ water, while $\mathrm{NaCl}$ cured hides and skins contain approximately 30\% moisture (Munz, 2007). Therefore, the silicate cured hides and skins were very stiff and hard, but there was no problem to re-hydrated them, and no impact was found on the leather quality (Munz, 2007). More importantly, as shown in Figure 8, the application of neutralized alkali silicates for the preservation of raw hides and skins instead of $\mathrm{NaCl}$ results in $60 \%$ TDS reduction and tolerably full salt elimination in soaking liquors. Furthermore, application of soaking liquors from silicate cured raw materials in place of purity water for irrigation leads to improve the plant production (Munz, 2007). It seems that the irrigation water containing certain silicate contents supports plant growth. In short, neutralized alkali silicates can totally replace $\mathrm{NaCl}$ curing in the preservation of raw hides and skins, autocephalous whether neutralized alkali silicates are applied as powder or formed in raw materials by chemical reaction (Munz, 2007).
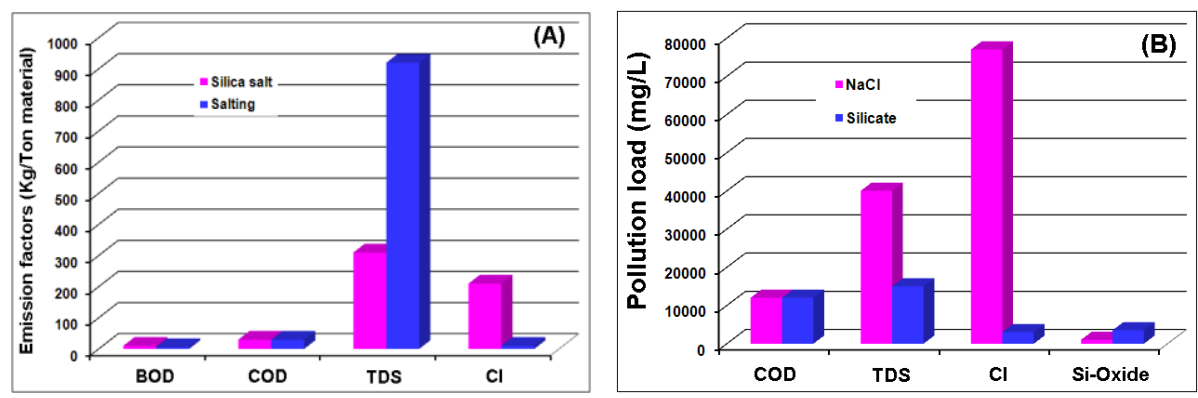

Figure 8 Comparison of effluent parameter from powder application (A) and drum procedure (B) (Munz, 2007).

\subsection{Peracetic acid}

Valeika et al. (2016) investigated the short-term preservation of hides and skins using the strong oxidizer of peracetic acid (PAA) and evaluated the impact of preservation on collagen and on processed leather qualitative properties. It was found that the treatment of fresh hide by a mixture of $\mathrm{H}_{2} \mathrm{O} 100 \%$, sodium hydroxide $0.5 \%$, hydrogen peroxide $0.3 \%$ and acetic anhydride $1.5 \%$ (\% based on freshe hide weight) at $15-20{ }^{\circ} \mathrm{C}$ during $2 \mathrm{~h}$ allowed preservation 
of hide during 20 days at temperature $22 \pm 1{ }^{\circ} \mathrm{C}$. The prolongation of the treatment duration more than $2 \mathrm{~h}$ does not increase the preservation effect obviously but affects hide structure at these higher levels. The increase of concentration of materials used for the treatment results in significant decrease of hide shrinkage temperature, and the shrinkage temperature decrease continues during all the storage time of hide (Valeika et al., 2016). Hide preserved by PAA is more sensitive for chemicals during technical procedures and, because of this, its derma structure is opened in higher level than derma of cured by $\mathrm{NaCl}$ control (Valeika et al., 2016). Herewith, it binds more chromium compounds (Table 2) during main and additional chroming processes. Leather produced from hide preserved by oxidative method characterizes by slightly lower tensile and grain strength comparing with conventionally produced leather. The use of proposed short-term preservation of hide allows a more than 11 fold reduction of $\mathrm{Cl}^{-}$concentration in tannery effluent (Valeika et al., 2016).

Table 2 Properties of crust leathers produced from hides preserved by oxidative method (OxH) and salt control (SaltH) (Valeika et al., 2016).

\begin{tabular}{|l|c|c|}
\hline \multirow{2}{*}{ Index } & \multicolumn{2}{|c|}{ Crust leather produced from hide } \\
\cline { 2 - 3 } & OxH & SaltH \\
\hline $\mathrm{Cr}_{2} \mathrm{O}_{3}$ content [\%] & 4.7 & 4.2 \\
\hline Matter soluble in dichloromethane [\%] & 10.9 & 10.8 \\
\hline Volatile matter [\%] & 10.6 & 10.5 \\
\hline Tensile strength [N/mm $\left.{ }^{2}\right]$ & 18.2 & 18.9 \\
\hline Strain when grain breaks [N/mm $\left.{ }^{2}\right]$ & 17.4 & 18.9 \\
\hline Relative elongation at break [\%] & 68.0 & 62.5 \\
\hline
\end{tabular}

\section{Natural preservatives}

Many plant-based preservative formulations (Preethi et al., 2006; Kanth et al., 2009a, 2009b; Kannan et al., 2009a, 2009b, 2009c; Bayramoglu, 2006, 2007, 2010; Vijayalakshmi et al., 2009a; Musa et al., 2011; Iyappan et al., 2013; Kumar et al., 2014; Selvi et al., 2015; Colak et al., 2006a, 2006b, 2010; Zengin et al., 2014) have been reported for the preservation of animal skins and hides or as biocides used in the soaking process. As shown in Table 3, these natural materials are normally used as essential oils, extract and paste containing powdered plant or extract. Actually, the active components showing antimicrobial activity are the essential oils in these plants. Essential oils are the natural mixtures of the secondary metabolites from plants, and their main components are small molecules such as terpenes, aromatic, aliphatic compounds, nitrogen- and sulfur-containing compounds. Because of their eco-friendly property and antibacterial or /and antifungal activities, leather chemists have been investigating for their possibility to be used as alternatives to salt used to preserve skins and hides.

Table 3 Plant preservatives studied in leather industry 


\begin{tabular}{|c|c|c|c|c|c|}
\hline Plants & Used form & Main ingredients & Objects & Origin & Year \\
\hline $\begin{array}{l}\text { Myrtus } \\
\text { communis }\end{array}$ & Essential oil & $\begin{array}{l}\text { 1,8-cineol, } \\
\alpha \text {-pinene, } \\
\text { limonene, linalool, } \\
\text { myrtenyl acetate, } \\
\alpha \text {-terpineol } \\
\end{array}$ & Soaking & Turkey & 2006 \\
\hline Oregano & Essential oil & $\begin{array}{l}\text { carvacrol, } \\
\gamma \text {-terpinen, thymol, } \\
\text { terpinen-4-ol, } \\
\text { para-cymene, }\end{array}$ & Soaking & Turkey & 2007 \\
\hline $\begin{array}{l}\text { Acalypha } \\
\text { indica }\end{array}$ & $\begin{array}{l}\text { Paste made by } \\
\text { ground leaves }\end{array}$ & $\begin{array}{l}\text { emodin, } \\
\beta \text {-sitosterol, } \\
\text { loliolide, nicotinic } \\
\text { acid, gallic acid, } \\
\text { rutin }\end{array}$ & Curing & India & 2006 \\
\hline $\begin{array}{l}\text { Sesuvium } \\
\text { portulacastru } \\
m\end{array}$ & $\begin{array}{l}\text { Paste made by } \\
\text { powder plant }\end{array}$ & $\begin{array}{l}\mathrm{NaCl}, O \text {-cymene, } \\
\alpha \text {-pinene, } \\
\text { 2- } \beta \text {-pinene, } \\
\text { trans-caryophyllen } \\
\text { e, } 1,8 \text {-cineole, } \\
\text { limonene, } \\
\alpha \text {-terpinene }\end{array}$ & Curing & India & 2009 \\
\hline $\begin{array}{l}\text { Salicornia } \\
\text { brachiata }\end{array}$ & $\begin{array}{l}\text { Paste made by } \\
\text { powder plant }\end{array}$ & $\mathrm{NaCl}$, flavonoid & Curing & India & 2009 \\
\hline $\begin{array}{l}\text { Siğla tree } \\
\text { (Liquidambar } \\
\text { orientalis Mill. } \\
\text { Var } \text { orientalis) } \\
\text { storax } \\
\end{array}$ & Essential oil & $\begin{array}{l}\text { carvacrol, } \\
\gamma \text {-terpinen, } \\
\text { P-cymene, Thymol, } \\
\text { Linalool, styrene }\end{array}$ & Soaking & Turkey & 2010 \\
\hline $\begin{array}{l}\text { Lawsonia } \\
\text { inermis } \\
\text { (henna) }\end{array}$ & $\begin{array}{l}\text { Aqueous extract of } \\
\text { hanna leaves }\end{array}$ & $\begin{array}{l}\text { terpenoids, } \\
\beta \text {-sistosterol } \\
\text { glucoside, } \\
\text { flavonoid, } \\
\text { limonene, carvol, } \\
(E) \text {-anethole, gallic } \\
\text { acid, coumarins, }\end{array}$ & $\begin{array}{l}\text { Antimicr } \\
\text { obial } \\
\text { agent of } \\
\text { leather }\end{array}$ & Sudan & 2011 \\
\hline $\begin{array}{l}\text { Semecarpus } \\
\text { anacardium }\end{array}$ & Nut extract & $\begin{array}{l}\text { terpenes, } \\
\text { flavonoids, } \\
\text { phenolics, } \\
\text { saponins, alkaloids, } \\
\text { glycosides } \\
\end{array}$ & Curing & India & 2013 \\
\hline $\begin{array}{l}\text { Citrus } \\
\text { sinensis peel }\end{array}$ & $\begin{array}{l}\text { PEG-Soduim } \\
\text { alginate } \\
\text { encapsulated } \\
\text { extract }\end{array}$ & $\begin{array}{l}\text { flavonoids, } \\
\text { phenolic acids }\end{array}$ & Curing & India & 2014 \\
\hline $\begin{array}{l}\text { Tamarindus } \\
\text { indica }\end{array}$ & $\begin{array}{l}\text { Paste containing } \\
\text { leaf extract }\end{array}$ & $\begin{array}{l}\text { flavonoids, } \\
\text { aliphatic acids, } \\
\text { vitamins }\end{array}$ & Curing & India & 2015 \\
\hline
\end{tabular}




\begin{tabular}{|l|l|l|l|l|l|}
\hline $\begin{array}{l}\text { Vegetable } \\
\text { tannins }\end{array}$ & $\begin{array}{l}\text { Extracts of } \\
\text { quebracho, mimosa, } \\
\text { gall-nut, chestnut, } \\
\text { valonia }\end{array}$ & $\begin{array}{l}\text { condensed and } \\
\text { hydrolysable } \\
\text { tannins }\end{array}$ & Soaking & Turkey & 2006 \\
\hline Tannic acid & $\begin{array}{l}\text { Powder form of } \\
\text { tannin }\end{array}$ & - & Soaking & Germany & 2014 \\
\hline
\end{tabular}

\subsection{Paste formulations}

In 2006, an herbal-based formulation prepared using Azardirachta Indica (common name: Neem tree) was investigated by Preethi et al. (2006) to replace $\mathrm{NaCl}$ for the preservation of raw goatskins. Fresh powders of Neem leaves were mixed with isopropyl alcohol (or crude liquid extract cucumber) to form crude paste formulations. This formulations were applied on the flesh side of goatskins ( $450 \mathrm{~g}$ per skin), and $40 \% \mathrm{NaCl}$ was used as control. The preserved skins were piled in the tannery yard with 40-75\% humidity at 26-32 ${ }^{\circ} \mathrm{C}$, and the quality of skins was checked periodically. After two weeks, the adhering material was scrapped off, and goatskins were processed into wet blues and crust leathers. Moreover, similar preservation experiments were repeated in actual field conditions in a rural location in India. No sign of putrefaction was found for all the tested skins in the laboratory and field experiments (Table 4). Other analysis results also indicated the good preservation efficiency of the plant formulation. Notably, in the soaking effluent, all the pollution parameters such as total solids, TDS, COD and chloride showed dramatically reduction in the experimental cases because no salt was used in the curing (Figure 9). The effluent without slat can be easily recycled after suitable treatment thus saving considerable cost on water consumption. Near zero solid waste discharge is possible if salt is replaced with the neem formulation in the preservation of goatskins. The scrapped off neem material can be composted and it has potential to be converted into organic compost with high nutritive value.

Table 4 Subjective assessment of goatskins after preservation* (Preethi et al., 2006).

\begin{tabular}{|l|l|l|l|l|l|l|}
\hline \multirow{2}{*}{ Properties } & \multicolumn{4}{|c|}{ Laboratory experiments } & \multicolumn{2}{c|}{ Field experiment } \\
\cline { 2 - 7 } & Exp. 1 & Control & Exp. 2 & control & Exp. 3 & Control \\
\hline Putrid odour & No & No & No & No & No & No \\
\hline Hair slip & $<1$ & No & $<1$ & No & $<1$ & No \\
\hline Duration & 2 weeks & 2 weeks & 2 weeks & 2 weeks & 30 days & 2 weeks \\
\hline Preservation & Normal & Normal & Normal & Normal & Normal & Normal \\
\hline $\begin{array}{l}\text { Wet back after } \\
\text { soaking }\end{array}$ & $100 \%$ & $100 \%$ & $100 \%$ & $100 \%$ & $100 \%$ & $100 \%$ \\
\hline
\end{tabular}

*Assessed subjectively by a panel of 3 sophisticated technicians/scientists. Exp. 1: formulation containing isopropanol; Exp. 2: formulation containing liquid extract of cucumber; Exp. 3: formulation containing isopropanol; Control: salt. 


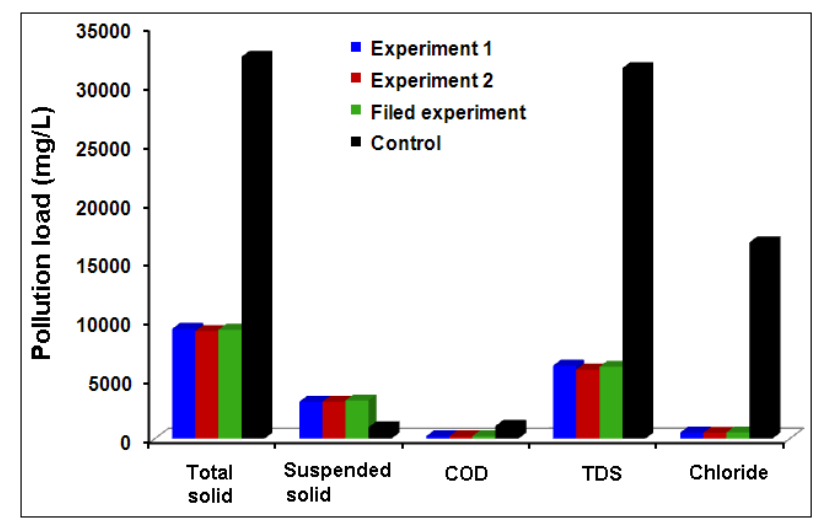

Figure 9 Pollution load generated in the soaking process (Preethi et al., 2006). Experiment 1: formulation containing isopropanol; Experiment 2: formulation containing liquid extract of cucumber; Field experiment: formulation containing isopropanol; Control: salt.

The salt tolerant halophytes including Sesuvium portulacastrum (S. portulacastrum) (Kanth et al., 2009a, 2009b; Kannan et al., 2009a) and Salicornia brachiata (S. brachiata) (Kannan et al., 2009b, 2009c) were explored to be used as curing agents for the preservation of raw skins. S. portulacastrum is capable of absorbing sodium chloride, and the absorbed salt is stored in its vacuoles. It has been found that the leaves of this plant contain around $18 \%$ (dry weight) of sodium and $15 \%$ chloride content. It showed excellent efficiency in the removal of $\mathrm{Na}^{+}$and $\mathrm{Cl}^{-}$from tannery wastewater treated soil (Kanth et al., 2009a; Kannan et al., 2009a), and its possibility to be used as an alternate to salt for the preservation of goatskins was also investigated (Kanth et al., 2009b). The preservation efficacy of the phyto-preserve may be attributed to the synergistic action its antimicrobial metabolites, essential oils, and the salt present in $S$. portulacastrum. The major chemical compounds present in the essential oils are terpinene, $\alpha$-pinene, camphene, $\beta$-pinene, bornyl acetate, tridecane, trans-carryoohyllene and $\alpha$-humulene (Kanth et al., 2009b). These components are toxic to microorganisms as they destroy the membrane integrity of bacteria or fungi. In experiments of Kanth et al. (2009b), the used S. portulacastrum was collected from salt marsh creeks land of Chennai in India, washed by soaking in tap water, dried and ground into fine powder (phyto-preserve) that was applied for preservation experiments as a paste prepared with $20 \%$ water. Various concentrations $(5-40 \%$, dry weight) of phyto-preserve were applied on the flesh side of goatskins, and the treated skins were pied and stored at ambient temperature of $35 \pm 3{ }^{\circ} \mathrm{C}$ for one month. As shown in Table 5, at a concentration of $10 \%$ dry weight, phyto-preserve can markedly inhibit bacterial growth in raw goatskins, and its effective preservation of goatskin was also confirmed by the results from moisture content, shrinkage temperature and total extractable nitrogen. Moreover, the quality of the preserved skins was found to be on par with that of salt cured skins, and the quality of resultant leathers was also comparable with control. Hence, the curing system using $S$. portulacastrum (phyto-preserve) provides an eco-friendly option to get over the environmental constrains of using salt (Kanth et al., 2009b). This study substantiates that phyto-preserve can be used effectively as an alternative curing agent to salt, and no sophisticated instrument or new skill is required. On the side, phyto-preserve dose not pose any health or safety problem on utilization (Kanth et al., 2009b).

Table 5 Bacterial count (CFU/g of skin) of salt and phyto-preserved goatskins (Kanth et al., 2009b).

\begin{tabular}{|l|l|l|}
\hline Duration & Control & Bacterial count at different \% offer of phyto-preserve \\
\hline
\end{tabular}




\begin{tabular}{|c|l|c|c|c|c|}
\hline (days) & $(40 \%$ salt $)$ & 5 & 10 & 20 & 40 \\
\hline 0 & $2 \pm 0.10 \times 10^{3}$ & $2 \pm 0.10 \times 10^{3}$ & $2 \pm 0.13 \times 10^{3}$ & $2 \pm 0.11 \times 10^{3}$ & $2 \pm 0.09 \times 10^{3}$ \\
\hline 1 & $9 \pm 0.04 \times 10^{10}$ & $13 \pm 1.2 \times 10^{10}$ & $9 \pm 0.05 \times 10^{10}$ & $4 \pm 0.04 \times 10^{9}$ & $2 \pm 0.06 \times 10^{9}$ \\
\hline 2 & $8 \pm 0.04 \times 10^{9}$ & - & $5 \pm 0.04 \times 10^{7}$ & $6 \pm 0.04 \times 10^{6}$ & $2 \pm 0.02 \times 10^{6}$ \\
\hline 7 & $6 \pm 0.04 \times 10^{8}$ & - & $7 \pm 0.02 \times 10^{6}$ & $9 \pm 0.03 \times 10^{5}$ & $5 \pm 0.03 \times 10^{5}$ \\
\hline 14 & $5 \pm 0.03 \times 10^{7}$ & - & $4 \pm 0.03 \times 10^{5}$ & $3 \pm 0.03 \times 10^{5}$ & $6 \pm 0.02 \times 10^{4}$ \\
\hline 21 & $8 \pm 0.03 \times 10^{6}$ & - & $5 \pm 0.05 \times 10^{4}$ & $4 \pm 0.02 \times 10^{4}$ & $2 \pm 0.01 \times 10^{3}$ \\
\hline 30 & $4 \pm 0.02 \times 10^{6}$ & - & $8 \pm 0.02 \times 10^{4}$ & $5 \pm 0.03 \times 10^{3}$ & $3 \pm 0.02 \times 10^{3}$ \\
\hline
\end{tabular}

\subsection{Essential oils}

The essential oils of Myrtus communis is the first to be investigated in 2006 as a bactericide used in the soaking process (Bayramoglu, 2006). 1\% myrtle oil was applied in comparison with a commercial bactericide which is commonly used in the leather industry (typically containing 7-25\% phenol, 4-chloro-3-methyl). The essential oil was diluted with ethanol 1/1 (v/v) and then added to the main soaking liquor for sheep skins. This diluted oil was used for a 24 hour soaking period following a one hour pre-soaking (Bayramoglu, 2006). As shown in Figure 10, myrtle oil and commercial bactericide showed similar antibacterial effect in the soaking float, and so it would be suitable for use in industry.

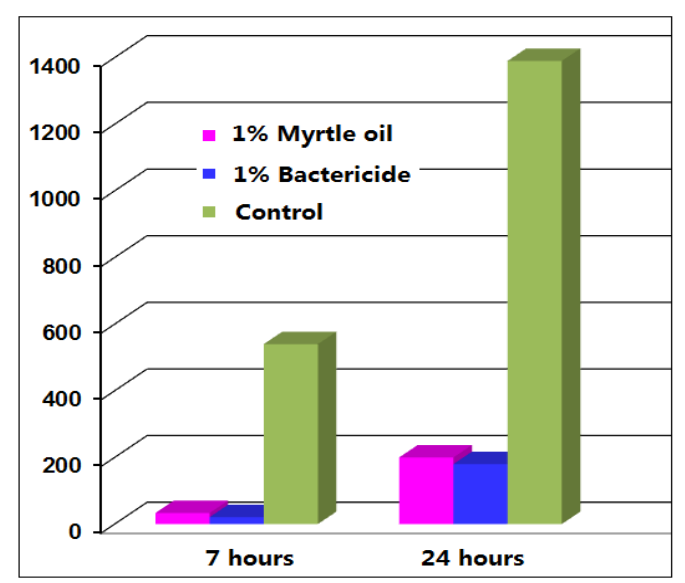

Figure 10 Total number of aerobic bacteria $\left(\times 10^{4}, \mathrm{cfu} / \mathrm{ml}\right)$ after 7 and 24 hours soaking (Bayramoglu, 2006).

Recently, an eco-friendly method for short term preservation of skins/hides using Semecarpus anacardium nut extract was explored by Iyappan et al. (2013). The acetone extract of $S$. anacardium dry nut at different concentrations showed antimicrobial activity (Figure 11), which is resulted from its phytochemicals like terpenes, flavonoids, phenolics, saponins, alkaloids and glycosides. The extract was applied on the flesh sides of goatskins, and $40 \%$ salt was served as control (Iyappan et al., 2013). During the period of preservation (30 days), skins were assessed periodically for various physical and chemical parameters like 
volatile nitrogen content, moisture content, bacterial count and shrinkage temperature. Especially, the stability and fiber structure of the collagen extracted from preserved skin samples were analyzed by running sodium dodecyl sulfate-polyacrylamide gel electrophoresis (SDS-PAGE). As shown in Figure 12, the banding pattern observed was similar in both the treatment confirming that collagen was not degraded or affected by the treatment with the plant extract. From the results obtained, the nut extract of this plant at $1 \%(\mathrm{w} / \mathrm{w})$ concentration is capable of preserving the freshly flayed skins for more than 30 days, and this curing method is an eco-friendly option to overcome the environmental problems produced by using salt (Iyappan et al., 2013).
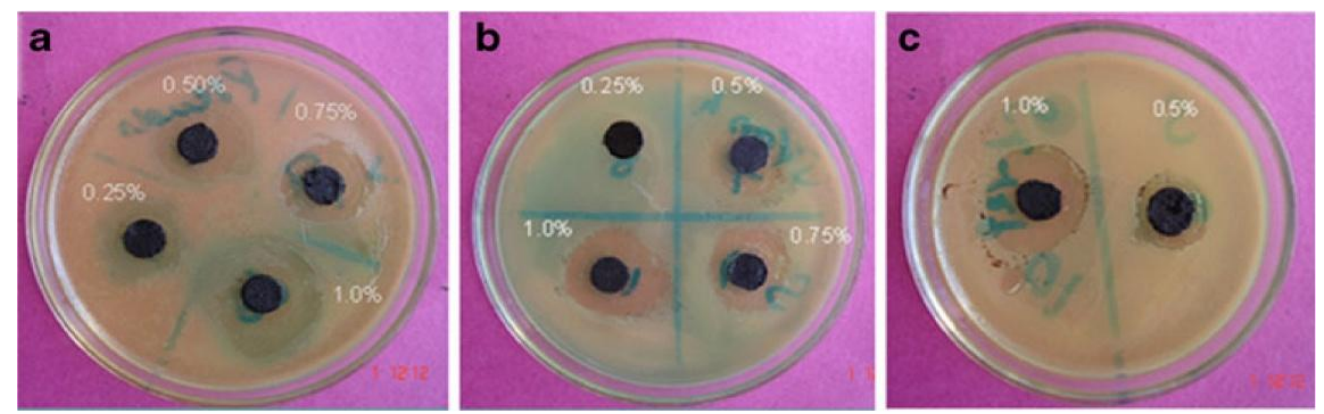

Figure 11 Antibacterial property of $S$. anacardium against Bacillus subtilis (a) Staphylococcus aureus (b) and Streptococcus pyogenes (c) (Iyappan et al., 2013).

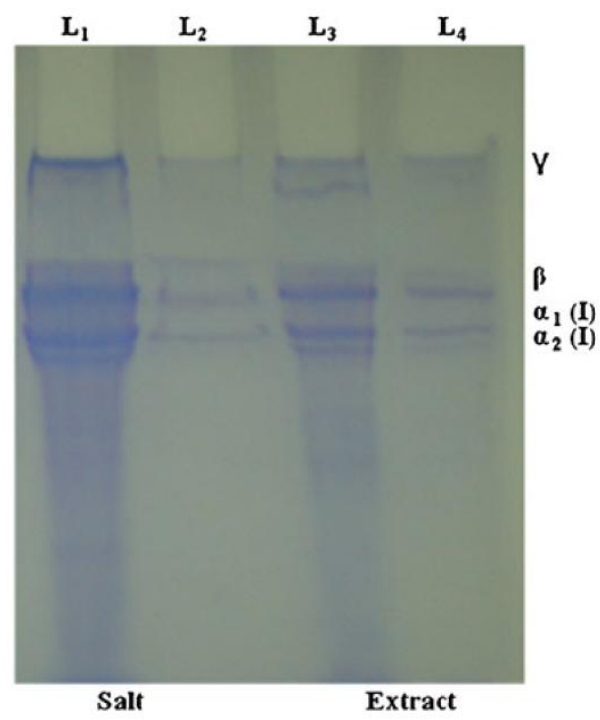

Figure 12 SDS-PAGE of collagen extracted from $S$. anacardium and salt-preserved skin samples after 30 days of preservation (Iyappan et al., 2013). Lane 1, 2 - 25 and $10 \mu \mathrm{g}$ of salt-treated collagen respectively; Lane 3, $4-25$ and $10 \mu \mathrm{g}$ of extract-treated collagen respectively.

\subsection{Chlorophyll}

Colak et al. (2006b) determined the suitability of the chlorophyll photosensitizer as biocides in the soaking process. All photosensitizers kill the microorganisms in the 
environment by generating singlet oxygen with the energy they receive from sunlight. Oxygen has a toxic effect not only on anaerobic types, but also on the living beings that depend on oxygen to survive. This study explored the neutralization or the restriction of the effects of the bacteria in the float during soaking by using the oxygen effect of chlorophyll, which is a photosensitizer that all the green plants in nature contain in great amounts (Colak et al., 2006b). With regards to this, the chlorophyll extracted from spinach leaves was used in the soaking process and its effect on the total aerobic mezophyll bacteria was determined compared with the effect of a commercial bactericide (Colak et al., 2006b). Results show that both the bactericide and chlorophyll were effective against bacteria. The effect of chlorophyll is increased with increasing amounts. Chlorophyll, which is easy to obtain from every green plant in nature, can be used during soaking process as an alternative and eco-friendly biocide. This method is important for the future in the sense that it employs a natural product and causes less pollution and its efficacy does not decrease as a result of the gradually increased resistance of bacteria against many biocides (Colak et al., 2006b).

\subsection{Antibiotics}

Proteolytic activity of extremely halophilic microorganisms, present in the salt used for hide preservation, can digest the grain surface of hides. Many bactericides have therefore been used in the leather industry to prevent damage by halophiles. However, natural proteinaceous antimicrobial substances such as halocins which are produced by halophilic archaea may be an effective and pollution free alternative to inhibit the proteolytic halophilic archaea in brine solutions. For the above reason, Birbir et al. $(2004,2007)$ conducted a microbial survey of the salt and brine samples collected from different salt sources in Turkey. Many of extremely halophilic strains were isolated from these salt sources, and the most potent halocin producers were found. It is implied that gelatinase negative halocin producers or their halocin extracts may be used in preventing the halobacterial deterioration that can exist during brine curing of hides when using crude salt from whatever source.

In 2014, Kanagaraj et al.(2014) evaluated a new acteriocin, extracted from Lactobacillus plantarum isolated from chicken meat by submerged fermentation method, as a potential short-term preservative for goat skins. The bacteriocin revealed antimicrobial activity against the skin putrefying organism Pseudomonas aeruginosa and Bacillus putrefaciens by plate assay method (Kanagaraj et al., 2014). These two cultures were further analysed by SEM (Figure 13), which showed cleavage of bacterial cell walls due to action of bacteriocin. Then the bacteriocin was tested for preservation of goat skin infected by skin putrefying organisms of Pseudomonas aeruginosa and Bacillus putrefaciens, and its efficacy was studied. The microbial infected goatskin was preserved with $15 \%$ bacteriocin solution and stored for seven days at ambient temperature, which showed the thorough inhibition of microbial growth even after seven days of storage (Kanagaraj et al., 2014). The goatskin was further processed into crust leather that was analysed by SEM and physical testing data. These data revealed no significant changes in the fiber structure of the skin due to preservation by bacteriocin. The pollution load generation has reduced at the level of 94.4\% (TDS) and 95.6\% (chlorides) during soaking process. The overall experiments revealed that the bacteriocin can be used as 
potential biopreservatives for preservation of skin and leather.
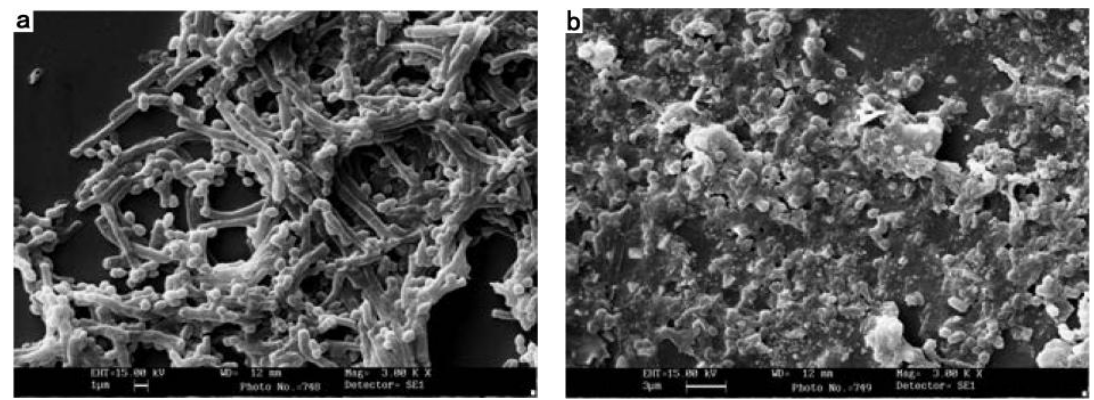

Figure 13 Scanning electron micrographs of Bacillus cereus control (a) and treated with partially purified bacteriocins (b) (Kanagaraj et al., 2014).

The use of antibiotics requires careful deliberation regarding both the criteria for their selection and the methodology of their application. Certain widely available antibiotics, including Doxycycline $\mathrm{HCl}$, have demonstrated activity for short-term preservation of fresh hides. By eliminating the requirement of dry salt or brine curing, there are potential major benefits from reduced environmental burden. When used in the soak, such antibiotics may prove to be an economical alternative to conventional antimicrobials currently used for this purpose (Stockman et al., 2007; Qin et al., 2014). However, evaluation of the use of clinically significant antibiotics must take into consideration other factors besides effectiveness in hide preservation or bacterial protection during soaking (Stockman et al., 2007). Before all, we must consider potential long-term risks associated with non-therapeutic applications of molecules that have been shown to be available human antibiotics. Before adopting extensive use of clinical antibiotics in hide preservation and soaking, it would be sensible to weigh the benefits and the potential impacts of such uses in the broadest context of global politics, health, and business decision-making (Stockman et al., 2007).

\section{Synthetic preservatives}

\subsection{PEG}

Polyethylene glycol (PEG) is a flexible, inert, water soluble polymer of ethylene oxide having excellent biocompatibility, biodegradability and specific interaction with biological systems. Due to the high flexibility and hydrophilicity of its main chain, PEG can combine with lots of water molecules through hydrogen-bond interaction. It has an ability to create very high osmotic pressures dehydrating quickly proteins which help as a precipitant for protein crystallization (Roberts et al., 2002). The extending use of PEG and its neutral charge behavior gives positive insight to replace salt for curing (Saravanabhavan et al., 2007; Rao et al., 2009; Kannan et al., 2010; Subramanian et al., 2014; An et al., 2012; Aldema-Ramos et al., 2015a, 2015b). Moreover, the little tendency to denature or to specifically interact with proteins even when reside in high concentrations and at elevated temperatures provides a possible option to use it as a curing agent without any further chemical modification of the virgin macromolecules. The underlying principle for selecting PEG for preservation can be 
shown in Figure 14 (Subramanian et al., 2014). The PEG-water interaction is truly significant, a minimum of $\sim 2-3$ water molecules per PEG monomer seems to be required to complete basic hydration. PEG can be used to remove water from the matrix of hide though hydrostatic pressure. The water present in the hide matrix as free form can be replaced by PEG molecule, which is represented as dehydration process. Consequently, the favorable condition of the hide matrix for the growth of microorganism is altered. Further, the PEG molecules coat the individual fiber bundles thus avoiding the fiber cohesion of the hide matrix. The PEG coated fiber bundles are quickly rehydrated (wetted) when the matrix suffers from rehydration process (soaking). During the rehydration process PEG molecules move out from the hide matrix and synchronously water enters inside the matrix, which is represented as rehydration process (Figure 14b). This is mainly because of the presence of hydrophilic groups in PEG resulting in quick wetting process. Therefore, the fiber bundles are again associated with water molecules, when the matrix is rehydrated (Subramanian et al., 2014).
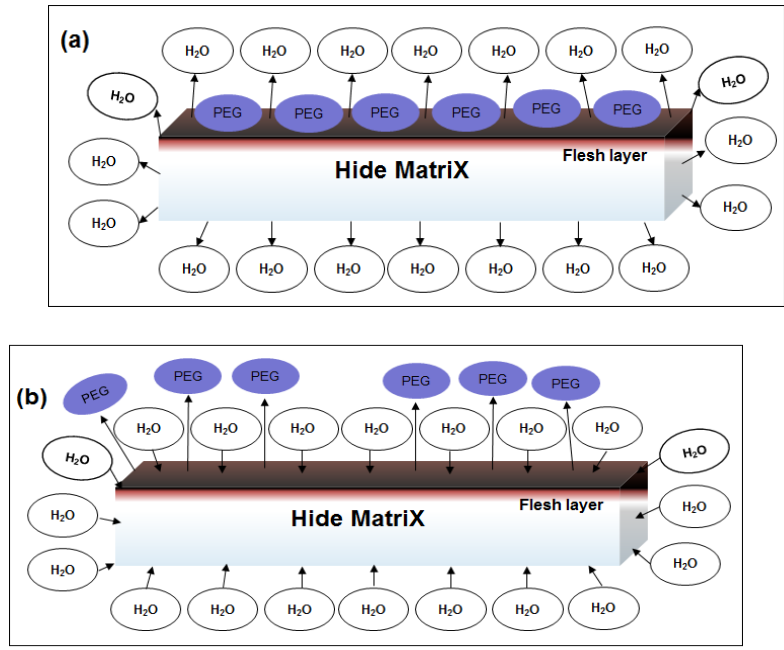

Figure 14 Schematic representation of (a) dehydration process of hide matrix by PEG and (b) rehydration process of PEG treated hide matrix (Subramanian et al., 2014).

Rao et al. (2009) first explored the possibility to completely replace salt with PEG for preservation of goat skins to achieve greener leather processing. The molecular percentage and weight offer of PEG were standardized based on the dehydration and rehydration profile of the preserved skin matrix (Figure 15) (Rao et al., 2009). PEG of different molecular weight from 200 to 1000 can reduce the moisture content to below 20\%, but only PEG 200 and 1000 follows an analogous dehydration pattern to that of wet salted skins (Rao et al., 2009). From the rehydration graph, it is obvious that the rehydration rates are comparable to that of the wet salted skins for all the molecular weight of PEG. The PEG 200 based preservation was found to be more efficient than the conventional method by the determination of hydroxyproline release in the soak liquors during various time periods of storage (Rao et al., 2009). The fiber orientation of the crust leather has been demonstrated through SEM analysis. Input-output analysis shows that the PEG200 based preservation process reduces the chemical input by 92.5\%. The pollutant loads of the developed preservation method using PEG200 was found to be $71,34,99,93 \%$ less in terms of BOD, COD, TDS and chloride, respectively, when 
compared with the conventional preservation method. Further, the physical and organoleptic properties of the crust leathers were found to be comparable to control crust leathers (Rao et al., 2009). Hence, the developed preservation method with 3\% offer of PEG200 seems to be a techno-economically potential alternative for salt-based preservation. Recently, Subramanian et al. (2014) also found that the preservation of hides using PEG 2000 was more effecient than sodium chloride according to the determination of hydroxyproline in spent soak liquors at various time periods during storage (Figure 16).
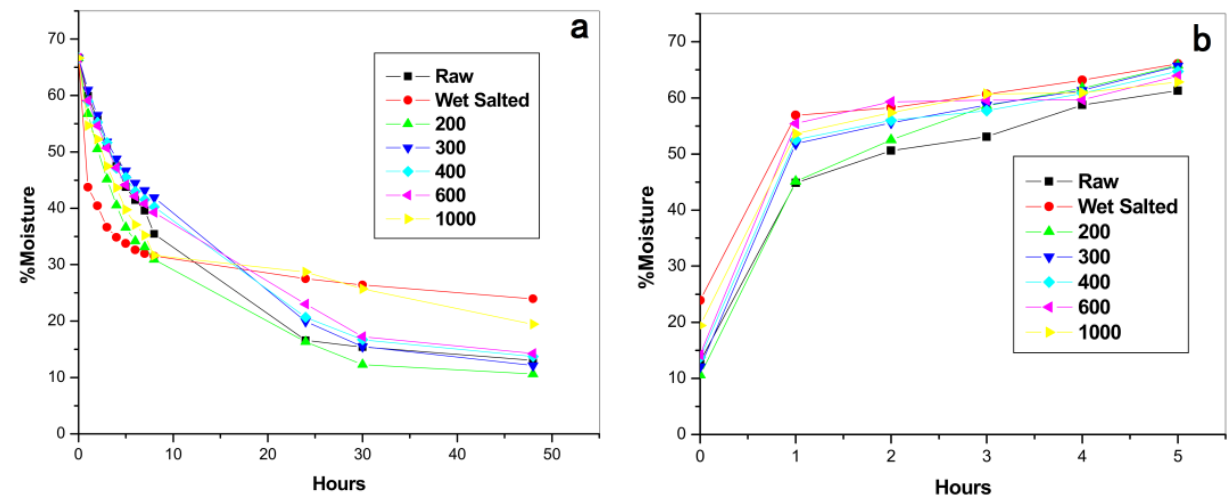

Figure 15 Dehydration (a) and Rehydration (b) profiles of preserved skins (Rao et al., 2009).

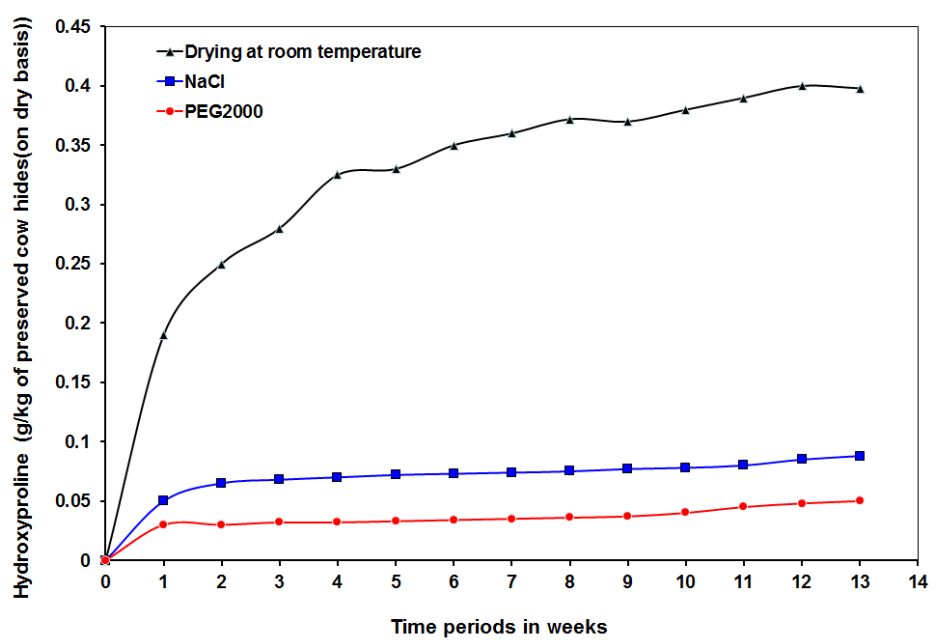

Figure 16 Effectiveness of preservation method by PEG2000, $\mathrm{NaCl}$ and drying at room temperature (Subramanian et al., 2014).

Also, Aldema-Ramos et al. (2015a, 2015b) investigated potential effects of incorporating PEG of different molecule weights with lower salt concentrations in the presence of crude glycerol (CG) and sodium carbonate (SC) for curing bovine hides for short-term preservation. The presence of glycerol counteracted the tendency for over drying caused by PEG, hence ameliorating the negative effects of excessive drying dincluding a tighter or more integrated interfibrillar structure that would require a longer rehydration period. Low molecular weight PEGs, notably PEG200, 400 and 600, were more effective than high molecular weight polymers (Aldema-Ramos et al., 2015a). Preservation was found to be 
efficient because no sign of putrefaction was observed in alternatively cured hides, and the properties of these hides were on par with those of traditionally preserved hides. When PEG was incorporated, the salt concentration required for hide preservation could be reduced. The developed standard formulation consisted of 5\% CG, $1 \% \mathrm{SC}, 20 \% \mathrm{NaCl}$, and 2\% PEG200 (/400/600) (Aldema-Ramos et al., 2015a). Therefore, rehydration of the alternative cured hide pieces reduced the chloride content from the 6-7\% range to $3 \%$ within 3-4 h. Potentially, less water could be used during rehydration and soaking prior to tanning the hides to leather since the starting amount of salt include in the low salt brining solutions was already quite low. Therefore the amount of wastewater discharged into the environment could relatively be reduced (Aldema-Ramos et al., 2015a). So far, the resulting crust leather products did not appear any signs of degradation of the collagen fibers. The presence of PEG and glycerol helped in the controlled drying process of the preserved hides and had active effect on quality of the resulting leather being more stretchable, stronger and softer than the control (Aldema-Ramos et al., 2015a). PEG, in the presence of CG and SC are quire desirable as ingredients in the new alternative less salt and eco- friendly hide preservation process (Aldema-Ramos et al., 2015a).

\subsection{Ozone}

Ozone is a strong oxidant and potent disinfecting agent. While the destruction of bacteria by ozone has been researched extensively on various food products, not much information is available on the effect of ozone on action with respect to preservation of raw skins/hides in leather making (Mutlu et al., 2009). Sivakumar et al. (2010) explored the possibility of ozone as a sterilant used for the short-term preservation of raw animal skins in leather making. Samples of fresh goatskins were exposed to ozone gas at $2 \mathrm{~g} / \mathrm{h}$ in a technically designed glass column reactor (Figure 17) for 0.5, 1, 1.5 and 2 hours, respectively, and microbial growth in skins for different experiments was monitored by visual density measurement from the skin washings. Under the given process conditions, the bacterial population was found to be absent for the skins even with $0.5 \mathrm{~h}$ time of exposure to ozone. As shown in Figure 18, ozonized samples kept in open atmosphere gave encouraging results and found to be as effective as control salting method while the samples kept in the sealed bag were started putrefying in 2 days possibly owing to anaerobic microbial activity. Therefore, the ozonization can be an effective alternative to salting of raw goatskin for preservation. This study opens up the probability of applying ozone technology for short-term preservation of skins and facilitates the removing of common salt used for conventional preservation thereby reducing the pollution load (Sivakumar et al., 2010). Appropriate design and development of ozone applicator for the preservation of raw skins for large scale could be useful (Sivakumar et al., 2010). 


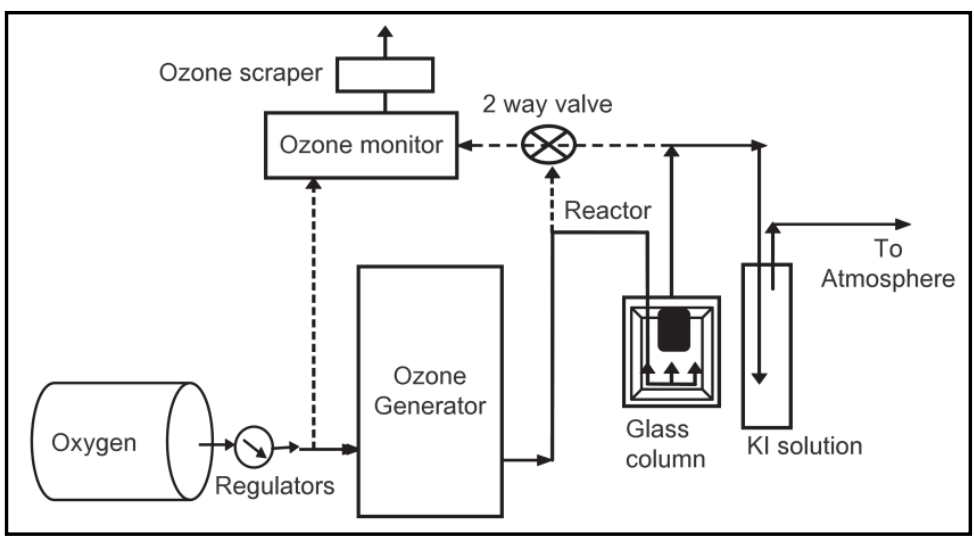

Figure 17 Schematic diagram of the ozone experimental setup (Sivakumar et al., 2010).

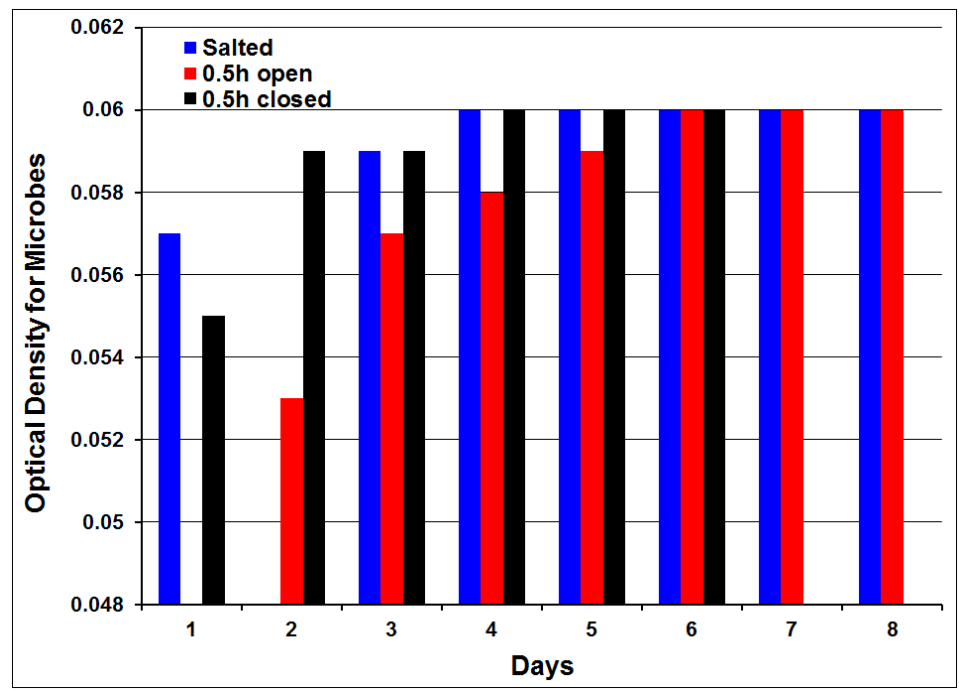

Figure 18 Microbial growth for 0.5 h ozonized samples and salted control (Sivakumar et al., 2010).

\subsection{Other chemical antiseptics}

Quaternary ammonium salts can denature bacterial cell proteins, interfere with metabolic processes and disrupt the cytoplasmic membrane of bacteria (Berber et al., 2010b; Veyselova et al., 2012, 2013; Peng et al., 2015). The mode of action of the cationic antibacterial agents starts with adsorption of the compounds to the bacterial surface, and then the agent diffuses through the cell wall and adheres to the cytoplasmic membrane. This disrupts the membrane, causing the release of $\mathrm{K}^{+}$ions and the cytoplasmic content, which finally leads to the death of microorganisms. Several quaternary ammonium salts, including dodecyl dimethyl benzyl ammonium chloride, didecyl dimethyl ammonium chloride and benzyl dimethyl hexadecyl ammonium chloride, were investigated for antibacterial effect, and found antibacterial application in the preservation of raw hide/skins and in the soaking process (Mutlu et al., 2009; Sivakumar et al., 2010; Berber et al., 2010b; Veyselova et al., 2012).

Valeika et al. (2013) recently proposed a mixture of benzoic acid $0.5 \%$ and acetic acid $0.6 \%$ (\% based on fresh skin weight) used as a short-term preservation method for pigskins, 
and preservation for 16 days at $22 \pm 1{ }^{\circ} \mathrm{C}$ was accomplished. The shrinkage temperature of skins during storage does not increase, inversely, it slightly decreases (about $7{ }^{\circ} \mathrm{C}$ ), and this limits the use of preservative mixtures containing more benzoic acid. Even so, the changes in the structure of the preserved skins stored for 14 days had no impact on the quality of leather produced, and the chemical and strength properties are comparable to the properties of leather produced from salt preserved pigskins.

\section{Physical preservative methods}

\subsection{Electric current}

Inactivation of bacteria by electric currents has received much attention due to its high efficiency, low cost, and ease of application (Birbir et al., 2006, 2008a, 2008c, 2008d, 2013b, 2013c, 2013d, 2014, 2015a, 2015b). Although mechanisms for microbial inactivation by low-level direct electric current has not yet fully understood, it is assumed that the completeness of the bacterial membrane and/or electrolyze molecules on the cell surface may be damaged by the electric current (Birbir et al., 2006). When the direct current is applied to bacterial cells, it can not only increase the energy of the membrane, but also influence the membrane lipids orientation and cell viability. What is more, since the voltage drop across it surpass $0.4-2 \mathrm{~V}$ or so, the bacterial cell wall decomposed. In the presence of chloride, oxygen, and chlorine dioxide, amount of chemical oxidants are produced in the condition that electric current is applied to aqueous bacteria suspensions with immersed electrodes. And most of these chemical oxidants are the cause of the lethality of applied direct current (Birbir et al., 2006).

Excellent work done by Birbir and her coworkers (Birbir et al., 2006, 2008a, 2008c, 2008d, 2013b, 2013c, 2013d, 2014, 2015a, 2015b) is notable in the electric inactivation of bacteria, especially halophilic ones, in hide-brine curing and soaking liquors. In 2006, they first investigated the effect of low-level, direct electric current on the inactivation of different kinds of extremely halophilic bacteria in brine solutions and this technique may be used in the leather industry (Birbir et al., 2006). As shown in Figure 19, Low-level electric current can kill different species of halophilic bacteria with treatment time of 5-20 min. The results showed that the electrical treatment system can be used as an efficient and simple method for inactivating protease, lipase, or lipase-plus-protease producers and a mixed culture of extremely halophilic bacteria species in the brine solutions that are used for raw hides preservation. This technique used in the leather industry may turn out to be more simpler, secure, and less expensive than the use of antibacterial agents (Birbir et al., 2006). 


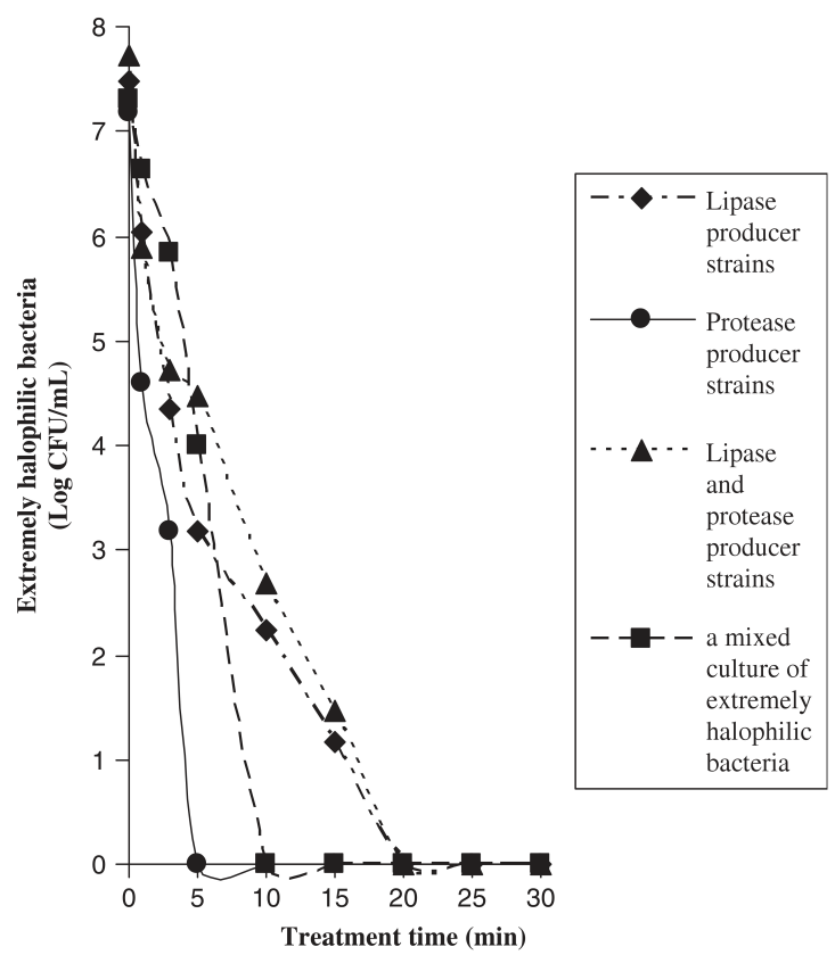

Figure 19 The effect of 0.5A low level direct electric current on lipase, protease, lipase and protease producing extremely halophilic bacteria and a mixed culture of extremely halophilic bacteria in liquid Brown media (Birbir et al., 2006).

Birbir et al. (2008c) also studied the effect of 2 A direct electric current on bacterial populations in the first and main hide-soak liquors using the electrolysis cell system shown in Figure 20. It can be seen that mesophilic bacteria in the soak liquors were inactivated after 20-50 min of electrical treatment. What is more, there was a correlation between the voltage level and the numbers of bacteria in the electrolysis cell. The bacterial populations in the hide-soak liquors decreased proportionally to the voltage level before all of the bacterial population was inactivated (Birbir et al., 2008c). After the bacteria in the hide-soak liquors were totally destroyed by direct electric current, the voltage level started to increase. This important clue might be used to forecast the inactivation time of all of the bacterial population in hide-soak liquors in the leather industry (Birbir et al., 2008c). It is suggested that the bacterial inactivation in hide-soak liquors by electrical treatment might be used in tanneries, which do not have a waste treatment system and discharge their wastewater directly into environment (Birbir et al., 2008c) . 


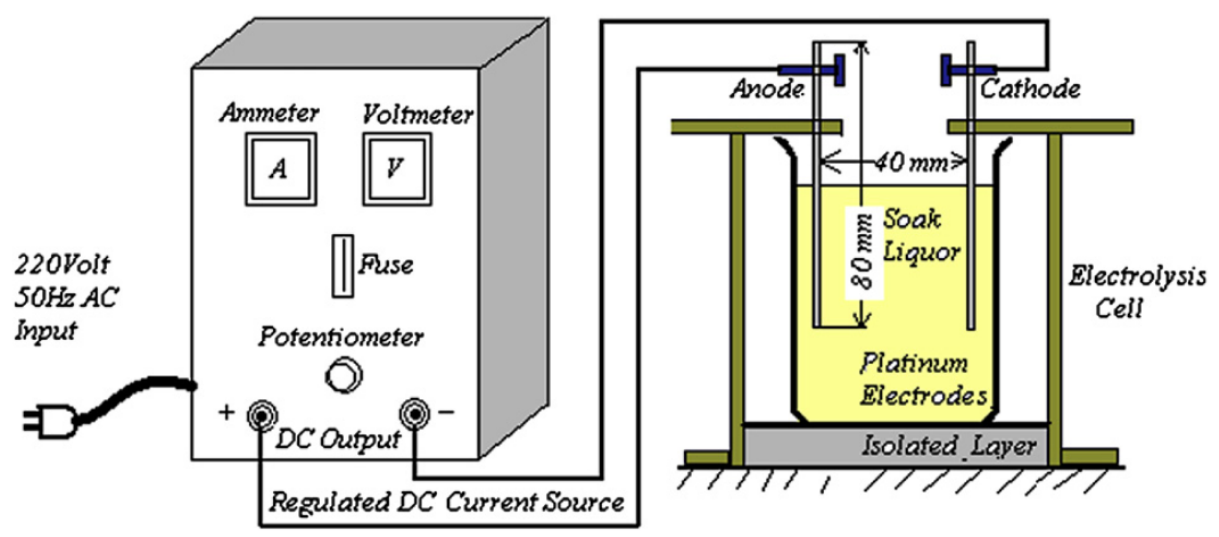

Figure 20 Schematic diagram of electrolysis cell system for soak liquor (Birbir et al., 2008c).

Recently, Birbir's group (2013b, 2013c, 2013d, 2014, 2015b) determined the effect of a combined treatment using both direct and alternating electric currents on hide bacteria including Gram negative, Gram positive bacteria and their mixed culture. For example, an electric treatment combining both $188 \mu \mathrm{A} / \mathrm{m}^{2}$ direct and $251 \mu \mathrm{A} / \mathrm{m}^{2}$ alternating electric current, applied for $16 \mathrm{~min}$, was found to be comparatively effective in reducing the bacterial cell count (7.10-7.48 $\log _{10}$ colony forming units/mL) to a relatively low level (4.52-4.90 $\log _{10}$ colony forming units/mL) (Birbir et al., 2013b). Furthermore, the collaborative effect of direct and alternating electric current treatments and bronopol to inactivate bacteria was found in hide-soak and hide-brine curing liquors (Birbir et al., 2014, 2015b). Their results showed that the electric current treatment helped penetration of bronopol into the damaged bacterial cells and increased the effectiveness of bronopol.

\subsection{Chilling}

Chilling is considered an alternative curing method for salt-free short-term preservation of hides and skins, but no systematic studies has been carried out with this method. Babu et al. (2012b) investigated the cold activity of the five major skin-borne bacteria at different temperatures and their collagenolytic activities. Bacillus sphaericus was found to be the most cold-tolerant bacterium exhibiting growth even at $2{ }^{\circ} \mathrm{C}$, while Macrococcus caseolyticus exhibited tolerance at $2{ }^{\circ} \mathrm{C}$ (Babu et al., 2012b). These two bacteria need to be controlled while designing a chilling method for the preservation of skins and hides. There is no relationship between collagenolytic activity at $37{ }^{\circ} \mathrm{C}$ and the cold activity, for instance, Bacillus firmus which exhibited the maximum activity at that temperature was found to be most cold-sensitive bacterium. They concluded that it is required to use a biocide in combination with chilling at $4{ }^{\circ} \mathrm{C}$ if the storage duration has to be extended beyond 9 days.

Babu and his coworkers (2012a) also carried out a systematic study on the role of chilling temperatures on the curing efficacy of hides and skins. Samples of goat skins and cow hides, chilled to different temperatures, were analyzed for the bacterial count, soluble nitrogen and hydroxyproline. The data suggested that $4{ }^{\circ} \mathrm{C}$ is the optimum temperature for 7 days storage, and there is the need for a blast chiller to chill down to the target temperature in less 
than 2 hours so as to minimize the chance for bacterial damage (Babu et al., 2012a). The optical microscopic studies (Figure 21) of the chilled hides and skins at different temperatures show that the fiber compaction increases with the decrease in temperature in comparison with the skins preserved with common salt. The quality of the leathers produced from skins and hides chilled at $4{ }^{\circ} \mathrm{C}$ was found to be comparable to the control leathers and fulfill all the trade requirements as evidenced from the physical testing, organoleptic assessment and scanning electron microscopic studies (Babu et al., 2012a).

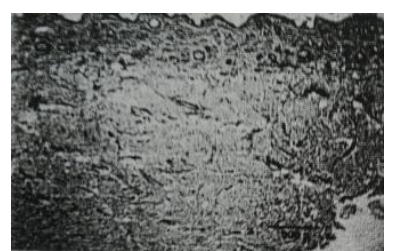

Cow hide control (Salted)

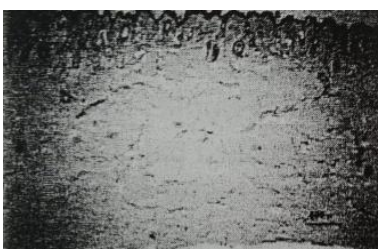

Cow hide chilled at $2{ }^{\circ} \mathrm{C}$

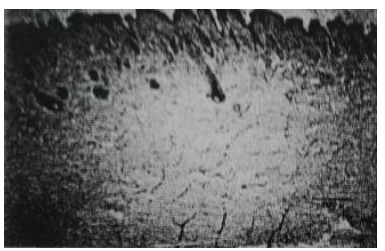

Cow hide chilled at $4{ }^{\circ} \mathrm{C}$

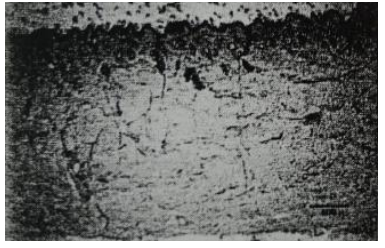

Cow hide chilled at $7{ }^{\circ} \mathrm{C}$

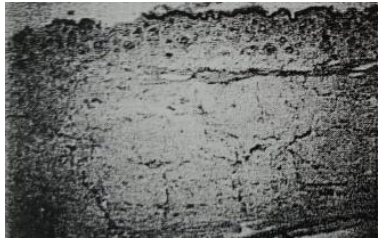

Cow hide chilled at $10{ }^{\circ} \mathrm{C}$

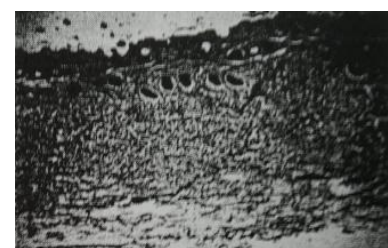

Goat skin control (Salted)

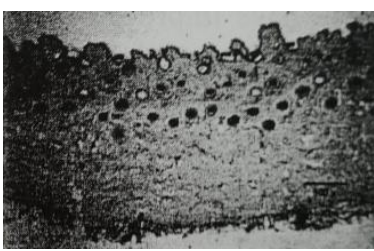

Goat skin chilled at $2{ }^{\circ} \mathrm{C}$

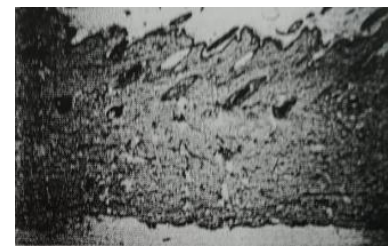

Goat skin chilled at $4{ }^{\circ} \mathrm{C}$

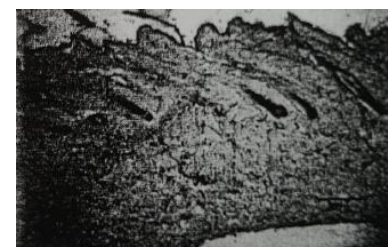

Goat skin chilled at $7{ }^{\circ} \mathrm{C}$

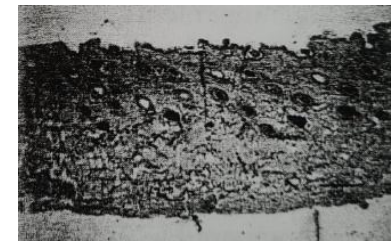

Goat skin chilled at $10{ }^{\circ} \mathrm{C}$

Figure 21 Optical microscopic images for preserved cow and goat skins (Babu et al., 2012a).

As shown in Figure 22, a mobile chiller suitable for salt-free preservation and storage of 
2 tons of raw hides and skins has been designed and fabricated by Babu et al. (2012c). The mobile chiller can chill the hides to $4{ }^{\circ} \mathrm{C}$ in less than 1 hour, and the safe duration of transportation is about 15 hours. The obtained results also identified that a considerable reduction in TDS and chloride pollution loads can be achieved, without any adverse effect on the final quality of the leathers, by the usage of the chilling method in place of conventional salt curing (Babu et al., 2012c).
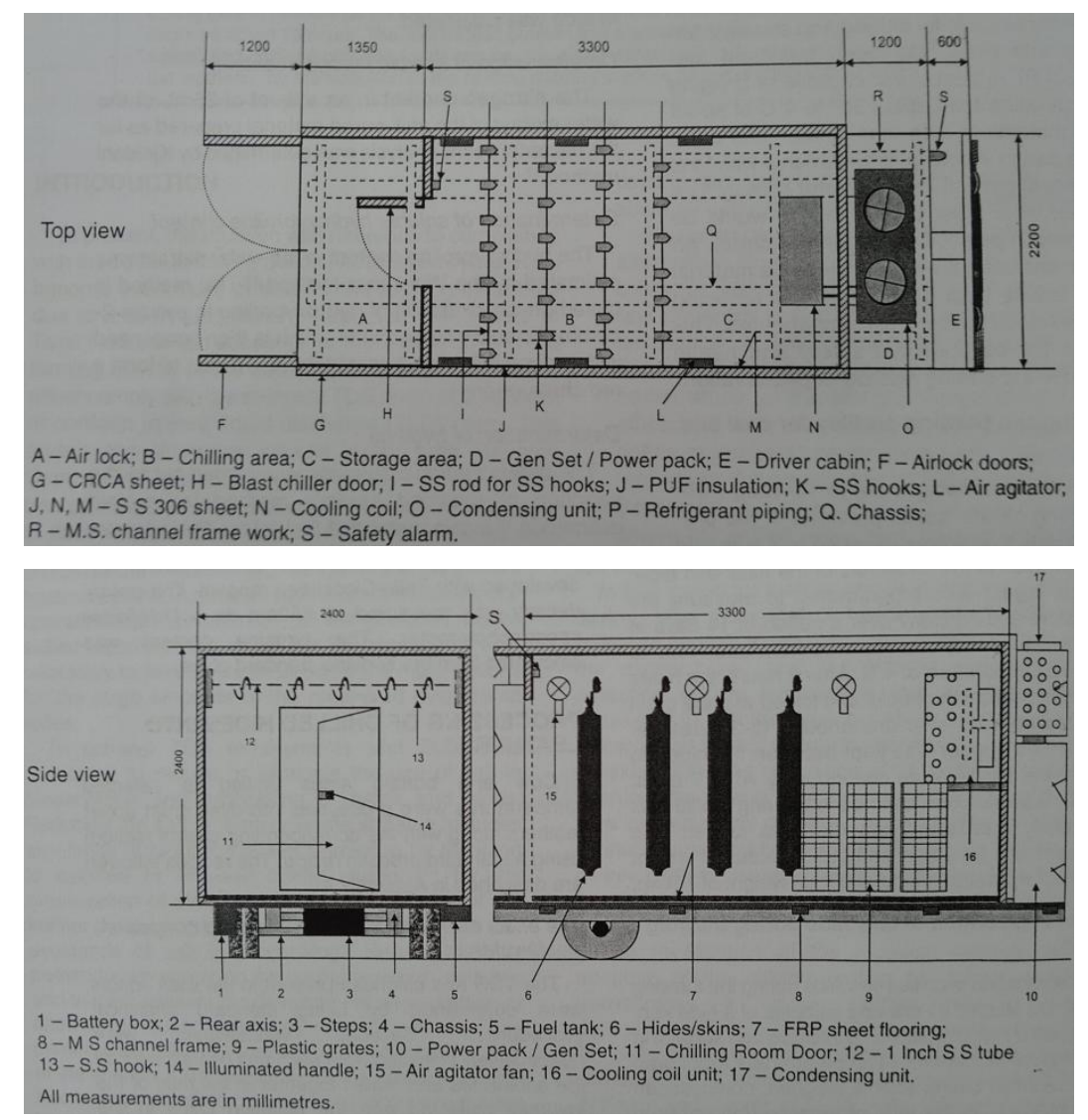

Figure 22 Design features of the mobile chiller (Babu et al., 2012c).

Furthermore, Narayanan et al. (2014) recently carried out a techno-management study to model a strategic supply chain network for collection and chilling of raw hides and skins appropriate for decentralized situations. Tamil Nadu state in India has been chosen for the pilot project, and eight clusters have been formed by grouping the districts of Tamil Nadu based on the geographical location. The optimized location for the chiller in each cluster was found using gravity location model and the possibility of transporting the raw hides and skins from slaughterhouse to chiller has been studied. The model can prove beneficial for the realization of chilling method of curing in decentralized collection systems that exist in many countries. Although the model has been studied for chilling method of short-term preservation of hides and skins, it can be adopted for any salt-free curing technique or for giving rise to any interventions for hides and skins quality improvement (Narayanan et al. (2014).

\subsection{Vacuum}


Gudro et al. (2014) investigated the influence of vacuum on hide storage time, structural changes and the properties of leather produced from hide preserved using a vacuum. Fresh calf hide samples were put into a special vacuum packaging film $\left(10-12 \times 10^{3} \mathrm{~Pa}\right)$ (Figure 23), and stored at $4{ }^{\circ} \mathrm{C}$ in a refrigerator (Gudro et al., 2014). The microorganisms act for all storage times (up to 21 days), but the action is weak and there is no observable impact on the quality of hide. It shows that intermolecular bonds of hide are not damaged with the slight decrease of the hide shrinkage temperature (Gudro et al., 2014). There is no structural change which can influence the quality of leather produced from such hide. However, in the process of skin into wet blue, the duration of hide preservation under vacuum and low temperature affects the level of collagen proteins removed. After 21 days of preservation in the processes of liming, deliming, bating and pickling, the amount of removed collagen proteins was higher than that from salted hide approximately 1.5 times. For all this, the produced leather bound more chromium compounds and had a higher shrinkage temperature (Gudro et al., 2014). Properties of the leather produced from vacuumed hide under industrial conditions meet the requirements of shoe upper leather. In conclusion, hide under vacuum and low temperature (4 ${ }^{\circ} \mathrm{C}$ ) can be stored for 21 days, and it won't reduce the quality of the leather produced (Gudro et al., 2014).
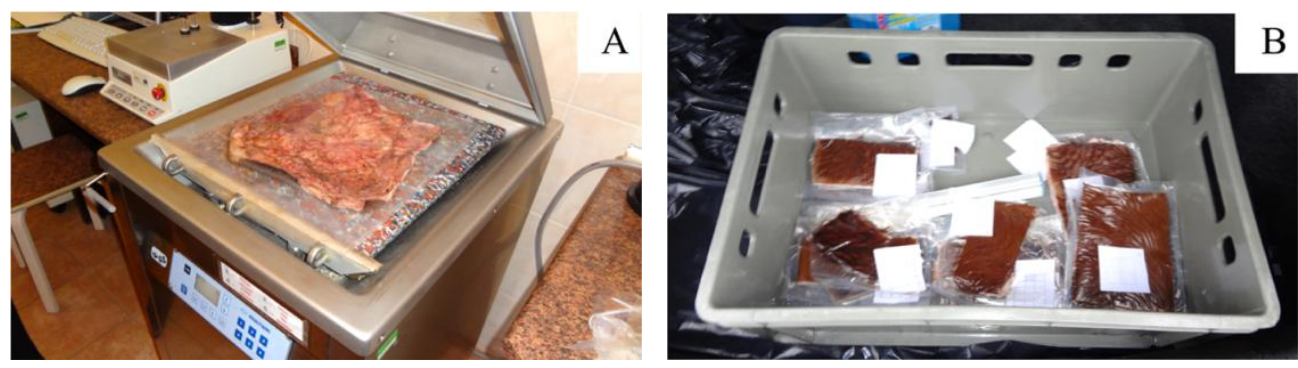

Figure 23 Equipment for fresh hide packing using vacuum (A) and the packed hide samples (B) (Gudro et al., 2014).

\section{Concluding Remarks}

The use of salt to preserve hides and skins is rapidly becoming untenable in today's world. Increasingly strict environmental legislations are obliging tanners to develop eco-friendly and cost-effective curing methods to replace the traditional salt curing that are polluting the environment. In assessing the merits of existing or proposed novel preservation methods, the criteria in Table 6 should be considered. Various preservation methods differ substantially with regard to the extent to which they meet the criteria whilst at the same time offering an economically viable approach to the preservation of hides and skins, and up to now, there is no perfect curing method for hides and skins. For the above discussed curing techniques, following points are proposed to be considered.

Table 6 Curing criteria (Russell et al., 1997)

(a) Stabilization of the physical and chemical properties of the skin for storage purposes; 
(b) Ease of transportation, i.e. cured stock should be lightweight and compact;

(c) Ease of grading, i.e. cured stock should be in a form conducive to handling and sorting;

(d) Reversibility, allowing for removal of the curing agent and restoration of the skin to its original state for processing;

(e) Non-polluting, i.e. having minimal environmental impact on reversal of the cure.

(1) Salt-less curing method, in which only a small amount of salt is used, is a practical and feasible route to reduce the load of TDS and chloride in tannery effluent. Under the circumstance that $\mathrm{NaCl}$ cannot be totally eliminated, it is advisable to reduce its utilization. Besides the high efficiency of preservation, the used alternatives to a part of $\mathrm{NaCl}$, normally water absorbing materials and bactericides, should not result in new environmental problems and cannot affect the future processing of raw hides and skins. Furthermore, cost is another factor that has to be considered. Some of the discussed salt-less curing formulations, for example, $\mathrm{NaCl}+$ silica gel, $\mathrm{NaCl}+\mathrm{SMB}$ and $\mathrm{NaCl}+\mathrm{BA}$, showed great potential to emerge as viable alternatives for the conventional salt preservation, but more research work should be done in the large-scale field trials.

(2) Much more attention should be paid on the salt-free (actually NaCl-free) methods. The reported $\mathrm{KCl}, \mathrm{Na}_{2} \mathrm{SO}_{4}$, silicate and peracetic acid are promising substitutes for $\mathrm{NaCl}$ used for the long and short term preservation of raw hides and skins. $\mathrm{KCl}$ is an almost perfect copy of salt curing without the environmental consequences associated with $\mathrm{NaCl}$, but the higher cost of $\mathrm{KCl}$ and the dependence of solubility on temperature precluded the use of this material for curing.

(3) Natural plant preservatives are highly potential to be taken as alternatives of salt, but some of their shortcomings must be overcome. For example, the volatility and instability of essential oils can hinder their durability as curing agents. The smells of some plant formulations are unpleasant. Furthermore, the contents and ratios of active ingredients can change with origin of corresponding plants, season, extracted parts and methods, which will directly result in the fluctuation of their preservative effects. The toxicity and environmental impact of plant preservatives should be fully assessed, too, as they are just mixtures of many chemical substances. More importantly, careful investigation should be done on natural preservatives according to their diversity and difference in place of origin and preservative activities.

(4) More systematical work is suggested to be carried out for the preservative application of macromolecular PEG with good biocompatibility and biodegradability. PEG is synthesized by anionic ring opening polymerization of ethylene oxide initiated by nucleophilic attack of a hydroxide ion on the epoxide ring. Due to the highly flexibility and hydrophily of main chain, PEG can combine with a large number of water molecules through the hydrogen bonding interaction, and it can quickly dehydrate protein by the produced high osmotic pressure. Furthermore, PEG coating on protein fiber surface can reduce or eliminate protein and bacterial adsorption (An et al., 2012). Based on these properties, PEG has great potential to be perfect alternative of salt for the preservation of hides and skins.

(5) Physical curing methods are normally not practical for the long-term preservation of 
hides and skins, but they are non-polluting alternatives for the short-term storage, and can be a beneficial supplement for chemical methods. Physical techniques including electric current, chilling, vacuum and irradiation (Bailey et al., 1999, 2001) are either energy-intensive or too complicated for little slaughterhouses, and need special and expensive machines, thus the widely adopting of them is restricted.

In summary, although some of the discussed curing methods are not very mature or too costly, they provide references for us to look for more efficient and environmentally friendly ways of raw hide preservation. I believe future preservation techniques will be efficient, clean, safe and diverse.

\section{Acknowledgements}

The project is financially supported by the National Science Foundation of China (No. 21106088) and the Ph. D. Programs Foundation of Ministry of Education of China (No. 20110181120079).

\section{References}

Akpolat, C., Ventosa, A., Birbir, M., 2015. Molecular identification of moderately halophilic bacteria and extremely halophilic archaea isolated from salted sheep skins containing red and yellow discolorations. Journal of the American Leather Chemists Association, 110(7), 211-220.

Aldema-Ramos, M. L., Muir, Z. E., Trusello, J., 2015a. Development of an alternative low salt bovine hide preservation using PEG and crude glycerol, part I: Evaluation of PEG molecular weight fractions. Journal of the American Leather Chemists Association, 110(4), 109-113.

Aldema-Ramos, M. L., Muir, Z. E., Uknalis, J., 2015b. Development of an alternative low salt bovine hide preservation using PEG and crude glycerol, part II: Mechanical properties of leather products. Journal of the American Leather Chemists Association, 110(5), 125-129.

An, R., Wang, C. H., Lin, W., 2012. Polyethylene glycol as leather preservatives effect of molecular weight and dosage. China Leather, 41(3), 29-32.

Aslan, E., Birbir, M. 2011a. Examination of efficiency and sufficiency of salt-pack curing method. Journal of the Society of Leather Technologists and Chemists, 95(3), 98-103.

Aslan, E., Birbir, M., 2011b. Examination of gram positive bacteria on salt-pack cured hides. Journal of the American Leather Chemists Association, 106(12), 372-380.

Aslan, E., Birbir, M., 2012. Examination of gram-negative bacteria on salt-pack cured hides. Journal of the American Leather Chemists Association, 107(4), 106-115.

Babu, N. K. C., Karthikeyan, R., Kumari, B. S., Ramesh, R., Shanthi, C., Sadulla, S., 2012a. A systematic study on the role of chilling temperatures on the curing efficacy of hides and skins. Journal of the American Leather Chemists Association, 107 (11) 362-374.

Babu, N. K. C., Kumari, B. S., Vimalarani, S. H., Shanthi, C., Karuthapandian, S., Sadulla, S., 2012b. Microbiological aspects of hide and skin preservation by chilling. Journal of the Society of Leather Technologists and Chemists, 96(2), 71-76.

Babu, N. K. C., Thiagu, R., Karthikeyan, R., Kumari, B. S., Ramesh, R., Sadulla, S., 
2012c. Using a mobile chiller for hides: a green method to resolve the TDS problem. Journal of the Society of Leather Technologists and Chemists, 96(5), 200-209.

Bailey, D. G., 1994. Preserving hides and skins with potassium chloride. Leather Manufacture, 112(12), 6-10.

Bailey, D. G., 1995. Preservation of cattle hides with potassium-chloride. Journal of the American Leather Chemists Association, 90(1), 13-21.

Bailey, D. G., 1999. Gamma radiation preservation of cattle hides. A new twist on an old story. Journal of the American Leather Chemists Association, 94(7), 259-266.

Bailey, D. G., 2003. The preservation of hides and skins. Journal of the American Leather Chemists Association, 98(8), 308-319.

Bailey, D. G., Birbir, M., 1996a. The impact of halophilic organisms on the grain quality of brine cured hides. Journal of the American Leather Chemists Association, 91(2), 47-51.

Bailey, D. G., Gosselin, J. A., 1996b. The preservation of animal hides and skins with potassium chloride. Journal of the American Leather Chemists Association, 91(12), 317-333.

Bailey, D. G., DiMaio, G. L., Gehring, A. G., Ross, G. D., 2001. Electron beam irradiation preservation of cattle hides in a commercial-scale demonstration. Journal of the American Leather Chemists Association, 96(10), 382-392.

Balada, E. H., Marmer, W. N., Cooke, P. H., Phillips, J. G., 2009. Evaluation of degreasers as brine curing additives. Journal of the American Leather Chemists Association, 104(5), 169-176.

Barinova, M., Kolomaznik, K., Vasek, V., Matyasovsky, J., Jurkovic, P., 2009. Optimization of raw hide curing using two-component counter-current diffusion model. Journal of the American Leather Chemists Association, 104(12), 397-404.

Bayramoglu, E. E. E., 2006. Antibacterial activity of Myrtus communis essential oil used in soaking. Journal of the Society of Leather Technologists and Chemists, 90(5), 217-219.

Bayramoglu, E. E., 2007. Unique biocide for the leather industry: Essential oil of oregano. Journal of the American Leather Chemists Association, 102(11), 347-352.

Bayramoglu, E. E., 2010. Possibility of using sigla tree (liquidambar orientalis Mill. Var orientalis) storax as bactericide in the soaking float. Journal of the American Leather Chemists Association, 105(2), 62-68.

Berber, D., Birbir, M., 2010a. Examination of bacterial populations in salt, salted hides, soaking hides and soak liquors. Journal of the American Leather Chemists Association, 105(10), 320-326.

Berber, D., Birbir, M., Hacioglu, H., 2010b. Efficacy assessment of bactericide containing didecyldimethylammonium chloride on bacteria found in soak liquor at different exposure times. Journal of the American Leather Chemists Association, 105(11), 354-359.

Berber, D., Birbir, M., Mertoglu, B., 2010c. Examination of bacterial and archaeal populations in salt, salted and soaked hide and soak liquors via fluorescent in situ hybridization. Journal of the Society of Leather Technologists and Chemists, 94(6), 259-261.

Bilgi, S. T., Yapici, B. M., Karaboz, S., 2015. Determination of hydrolytic enzyme capabilities of halophilic archaea isolated from hides and skins and their phenotypic and phylogenetic identification. Journal of the American Leather Chemists Association, 110(2), 
33-42.

Birbir, M., Eryilmaz, S., Ogan, A., 2004. Prevention of halophilic microbial damage on brine cured hides by extremely halophilic halocin producer strains. Journal of the Society of Leather Technologists and Chemists, 88(3), 99-104.

Birbir, Y., Birbir, M., 2006. Inactivation of extremely halophilic hide-damaging bacteria via low-level direct electric current. Journal of Electrostatics, 64(12), 791-795.

Birbir, M., Eryilmaz, S., 2007. Inhibiting lipolytic haloarchaeal damage on brine cured hides with halocin producer strains. Journal of the Society of Leather Technologists and Chemists, 91(2), 69-72.

Birbir, M., Ozdogru, Z. B., Birbir, Y., Ogan, A., 2008a. Extracellular protease activities of extremely halophilic archaea and their control via direct electric current. Journal of the Society of Leather Technologists and Chemists, 92(2), 53-58.

Birbir, Y., Degirmenci, D., Birbir, M., 2008b. Direct electric current utilization in destruction of extremely halophilic bacteria in salt that is used in brine curing of hides. Journal of Electrostatics , 66(7-8), 388-394.

Birbir, Y., Ugur, G., Birbir, M., 2008c. Inactivation of bacterial population in hide-soak liquors via direct electric current. Journal of Electrostatics, 66(7-8), 355-360.

Birbir, M., Cicek, R., Caglayan, P., Aslan, E., 2013a. An examination of inactivation efficacy of $\mathrm{NaCl}$ and boric acid on bacteria isolated from salted hides. Journal of the American Leather Chemists Association, 108(5), 171-179.

Birbir, Y., Dolek, N., Birbir, M., 2013b. Effect of a combined treatment using both direct and alternating electric currents on hide bacteria in hide-soak liquor. Journal of Electrostatics, 71(5), 898-904.

Birbir, Y., Dolek, N., Birbir, M., 2013c. Synergistic effect of direct and alternating electric current treatments and bronopol to inactivate bacteria found in hide soak liquors. Journal of the American Leather Chemists Association, 108(10), 373-385.

Birbir, Y., Molla, S., Birbir, M., 2013d. Applying electric current to inactivate gram-negative bacteria isolated from salt-packed-cured hides. Journal of the Society of Leather Technologists and Chemists, 97(1), 5-10.

Birbir, Y., Dolek, N., Birbir, M., 2014. Treatment using both direct and alternating electric currents on hide bacteria in brine curing and pre-soaking liquors. Journal of the Society of Leather Technologists and Chemists, 98(2), 47-55.

Birbir, Y., Anik, S., Birbir, M., Caglayan, P., 2015a. Annihilation of extremely halophilic archaea in gide preservation salt using alternating electric current. Johnson Matthey Technology Review, 59(2), 109-119.

Birbir, Y., Dolek, N., Birbir, M., Caglayan, P., 2015b. Extermination of bacteria in hide-brine curing liquors using combined alternating and direct electric current applications plus bronopol. Romanian Biotechnological Letters, 20(1), 10123-10133.

Cadirci, B. H., Ozgunay, H., Vural, C., Yilmaz, O., 2010. A new defect on leather microbial bio-film. Journal of the American Leather Chemists Association, 105(4), 129-134.

Caglayan, P., Sanchez-Porro, C., Ventosa, A., Birbir, M., 2015. Characterization of moderately halophilic bacteria from salt-pack-cured hides. Journal of the Society of Leather Technologists and Chemists, 99(5), 250-254. 
Colak, S. M., 2006a. Soaking with tannins: The biocidal activity of vegetable tannins used in the soaking float. Journal of the Society of Leather Technologists and Chemists, 90(5), 193-196.

Colak, S. M., Bayramoglu, E. E., Uluc, D., 2006b. Determining the suitability of photosensitizers as biocides in the soaking process. Journal of the American Leather Chemists Association, 101(2), 66-72.

Colak, S. M., Yapici, B. M., Yapici, A. N., 2010. Determination of antimicrobial activity of tannic acid in pickling process. Romanian Biotechnological Letters, 15(3), 5325-5330.

Covington, A. D., 2011. Tanning Chemistry, the Science of Leather; RSC Publishing: Cambridge.

Dixit, S., Yadav, A., Dwivedi, P. D., Das, M., 2015. Toxic hazards of leather industry and technologies to combat threat: a review. Journal of Cleaner Production, 87, 39-49.

Eduard, H. B., Marmer, W. N., Kolomaznik, K., Cooke, P. H., Dudley, R. L., 2008. Mathematical model of raw hide curing with brine. Journal of the American Leather Chemists Association, 103(5), 167-173.

Gudro, I., Valeika, V., Sirvaityte, J., 2014. Short term preservation of hide using vacuum: influence on properties of hide and of processed leather. PloS one, 9(11), e112783.

Hanlin, M. B., Field, R. A., Ray, B., Bailey, D. G., 1995. Characterization of predominant bacteria in cattle hides and their control by bacteriocin based preservative. Journal of the American Leather Chemists Association, 90(10), 308-320.

Iyappan, K., Ponrasu, T., Sangeethapriya, V., Gayathri, V. S., Suguna, L., 2013. An eco-friendly method for short term preservation of skins/hides using Semecarpus anacardium nut extract. Environmental Science and Pollution Research, 20(9), 6324-6330.

Kanagaraj, J., Babu, N. K. C., Sadulla, S., Rajkuma, G. S., Visalakshi, V., Chandrakumar, N., 2000. A new approach to less-salt preservation of raw skin/hide. Journal of the American Leather Chemists Association, 95(10), 368-374.

Kanagaraj, J., Babu, N. K. C., Sadulla, S., Rajkuma, G. S., Visalakshi, V., Kumar, N. C., 2001. Cleaner techniques for the preservation of raw goat skins. Journal of Cleaner Production, 9, 261-268.

Kanagaraj, J., Babu, N. K. C., 2002. Alternatives to salt curing techniques - A review. Journal of Scientific \& Industrial Research, 61(5), 339-348.

Kanagaraj, J., Sastry, T. P., Rose, C., 2005a. Effective preservation of raw goat skins for the reduction of total dissolved solids. Journal of Cleaner Production, 13(9), 959-964.

Kanagaraj, J., Sundar, V. J., Muralidharan, C., Sadulla, S., 2005b. Alternatives to sodium chloride in prevention of skin protein degradation - a case study. Journal of Cleaner Production, 13(8), 825-831.

Kanagaraj, J., Selvi, A. T., Senthilvelan, T., Babu, N. K. C., Chandrasekar, B., 2014. Evaluation of new bacteriocin as a potential short-term preservative for goat skin. American Journal of Microbiological Research, 2(3), 86-93.

Kanagaraj, J., Senthilvelan, T., Panda, R. C., Kavitha, S., 2015. Eco-friendly waste management strategies for greener environment towards sustainable development in leather industry: a comprehensive review. Journal of Cleaner Production, 89, 1-17. 
Kannan, K. C., Kumar, M. P., Rao, J. R., Nair, B. U., 2010. A novel approach towards preservation of skins. Journal of the American Leather Chemists Association, 105(11), 360-368.

Kannan, P. R., Deepa, S., Kanth, S. V., Rao, J. R., Gnanasekaran, C. S., Rengaswamy, R., 2009a. Studies on the use of sesuvium portulacastrum - Part III: Phytoremediation of salt contaminated soils of tannery wastewater discharged ilands. Journal of the American Leather Chemists Association, 104(12), 416-422.

Kannan, P. R., Deepa, S., Yasothai, A., Kanth, S. V., Rao, J. R., Chandrasekaran, B., 2009b. Phytoremediation of tannery wastewater treated lands. Part II: Using harvested salicornia brachiata plants for the preservation of sheepskins. Journal of the Society of Leather Technologists and Chemists, 93(6), 240-244.

Kannan, P. R., Kanth, S. V., Chandrasekaran, B., Rao, J. R., Gnanasekaran, C. S., Rengasamy, R., 2009c. Phytoremediation of tannery wastewater treated lands. Part I: Accumulation of $\mathrm{Na}^{+}$and $\mathrm{Cl}^{-}$in salicornia brachiata. Journal of the Society of Leather Technologists and Chemists, 93(6), 233-239.

Kanth, S. V., Kannan, P. R., Selvi, A. T., Saravanan, P., Rao, J. R., Nair, B. U., Rengaswamy, R., 2009a. Phytoremediation of soul using sesuvium portulacastrum - Part I: Removal of $\mathrm{Na}(+)$ and $\mathrm{Cl}^{-}$from tannery wastewater treated soil. Journal of the American Leather Chemists Association, 104(1), 17-24.

Kanth, S. V., Preethi, S., Keerthi, B., Selvi, A. T., Saravanan, P., Rao, J. R., Nair, B. U., 2009b. Studies on the use of sesuvium portulacastrum - Part II: Preservation of skins. Journal of the American Leather Chemists Association, 104(1), 25-32.

Kumar, M. P., Velmurugan, P., Sreeram, K. J., Rao, J. R., Nair, B. U., 2014. Reuse of solid waste from juice industry (citrus sinensis peel) in the extraction of antioxidants with enhanced activity through polymer encapsulates for the preservation of skin. Journal of the American Leather Chemists Association, 109(7), 231-238.

Lama, A., Allen, S. C., Attenburrow, G., 2012. Survival and growth of Bacillus cereus, pseudomonas aeruginosa and Staphylococcus aureus in extreme environments present during the early stages of a conventional leather making process. Journal of the American Leather Chemists Association, 107(6), 186-195.

Lama, A., Bates, M., Covington, A. D., 2013. Methods of isolation and identification of pathogenic and potential pathogenic bacteria from skins and tannery effluents. Journal of the American Leather Chemists Association, 108(2), 48-62.

Munz, K. H., 2007. Silicates for Raw hide curing. Journal of the American Leather Chemists Association, 102(1), 16-21.

Musa, A. E., Selvi, A. T., Aravindhan, R., 2011. Evaluation of antimicrobial activity of lawsonia inermis (henna) against microbial strains isolated from goat skin/leather. Journal of the American Leather Chemists Association, 106(5), 170-175.

Mutlu, M. M., Cadirci, B. H., Ozgunay, H., Adiguzel, A. C., Sari, O., 2009. Ozone as a biocide in soaking. Journal of the Society of Leather Technologists and Chemists, 93(1), 18-20.

Narayanan, P. A., Prasad, P. S. S., Chandramouli, D., Babu, N. K. C., 2014. Modeling a strategic raw hides \& skins supply chain network suitable for adoption of chilling method of 
preservation in decentralized collection system. Journal of the American Leather Chemists Association, 109(10), 353-362.

Ozgunay, H.; Colak, S.; Mutlu, M. M.; Akyuz, F., 2007. Characterization of Leather Industry Wastes. Polish Journal of Environmental Studies, 16 (6), 867-873.

Peng, H. J., Sang, J., Wang, C. H., Lin, W., 2015. Antibacterial activity of quaternary ammonium salts and preservative effect on raw skin. China Leather, 44(9), 19-23, 38.

Peng, H. J., Sang, J., Yu, L. Y., An, R., Mu, C. D., Lin, W., 2014. Analysis of leather preservative chemical and environmental risk. China Leather, 43(5), 48-50.

Preethi, V., Rathinasamy, V., Kannan, N., Babu, C., Sehgal, P. K., 2006. Azardirachta indica: A green material for curing of hides and skins in leather process. Journal of the American Leather Chemists Association, 101(7), 266-273.

Qin, Y. M., Xue, G., Zheng, X., Liu, L. N., 2014. Antiseptic performance study of GOD as hurdle factor on animal skin. Journal of the Hebei Academy of Sciences, 31(3), 68-70.

Rao, J. R., Kumar, M. P., Kannan, K. C., Nair, B. U., 2009. A polymer-based preservation: A new horizon in leather making. 30th Congress of the International Union of Leather Technologists and Chemists Societies, OCT 11-14, Beijing, Peoples R China.

Roberts, M. J., Bentley, M. D., Harris, J. M., 2002. Chemistry for peptide and protein PEGylation. Advanced Drug Delivery Reviews, 54 (4), 459-476.

Russell, A. E., 1998. The Liricure low salt antiseptic delivery system. World Leather, 11(5), 43.

Russell, A. E., Tandt, H., Kohl, R., 1997. Liricure-powder biocide composition for hide and skin preservation. Journal of Society of Leather Technologists and Chemists, 81(4), 137-142.

Saravanabhavan, S., Rao, J. R., Nair, B. U., Ramasami, T., 2007. An eco-efficient rationalized leather process. Journal of Chemical Technology and Biotechnology, 82(11), 971-984.

Selvi, A. T., Kanagaraj, J., Saravanan, P., 2015. Preservation of goatskin using tamarindus indica leaf extract - green process approach. Journal of the Society of Leather Technologists and Chemists, 99(3), 107-114.

Shede, P. N., Kanekar, P. P., Polkade, A. V., Dhakephalkar, P. K., Sarnaik, S. S., 2008. Bacterial succession on raw buffalo hide and their degradative activities during ambient storage. International Biodeterioration \& Biodegradation, 62(1), 65-74.

Sivakumar, V., Balakrishnan, P. A., Muralidharan, C., Swaminathan, G., 2010. Use of ozone as a disinfectant for raw animal skins-application as short-term preservation in leather making. Ozone-Science \& Engineering, 32(6), 449-455.

Stockman, G., Didato, D. T., Hurlow, E., 2007. Antibiotics in hide preservation and bacterial control. Journal of the American Leather Chemists Association, 102(2), 62-67.

Subramanian, S., Velmurugan, P., Rao, J. R., 2014. Green solution for salinity in tannery wastewater: A step forward in leather processing. Journal of the American Leather Chemists Association, 109(7), 214-223.

Ulusoy, K., Birbir, M., 2015. Identification and metabolic activities of bacterial species belonging to the enterobacteriaceae on salted cattle hides and sheep skins. Journal of the American Leather Chemists Association, 110(6), 186-199. 
Valeika, V., Beleska, K., Sirvaityte, J., 2016. Short-term preservation of hides and skins using peracetic acid. Journal of the American Leather Chemists Association, 111(1), 1-9.

Valeika, V., Beleska, K., Sirvaityte, J., Valeikiene, V., 2013. Short term preservation of skins with acids. Journal of the Society of Leather Technologists and Chemists, 97(3), 101-104.

Vankar, P. S., Dwivedi, A. K. R., 2009a. Raw skin preservation through sodium salts - A comparative analysis. Desalination, 249(1), 158-162.

Vankar, P. S., Dwivedi, A. K., 2009b. Sulphates for skin preservation - A novel approach to reduce tannery effluent salinity hazards. Journal of Hazardous Materials, 163(1), 207-212.

Vankar, P. S., Dwivedi, A., Saraswat, R., 2006. Sodium sulphate as a curing agent to reduce saline chloride ions in the tannery effluent at Kanpur: A preliminary study on techno-economic feasibility. Desalination, 201(1-3), 14-22.

Veyselova, C., Birbir, M., Berber, D., 2012. Quaternary ammonium compound as bactericide in hide brine curing and presoaking processes. Journal of the American Leather Chemists Association, 107(10), 336-341.

Veyselova, C., Birbir, M., Berber, D., 2013. Minimal bactericidal concentration for a quaternary ammonium compound used in soak liquors. Journal of the Society of Leather Technologists and Chemists, 97(4), 166-171.

Vijayalakshmi, K., Judith, R., Rajakumar, S., 2009a. Novel plant based formulations for short term preservation of animal skins. Journal of Scientific \& Industrial Research, 68(8), 699-707.

Vijayalakshmi, P., Rajeswari, G., Sundarapandiyan, S., Chandrasekar, R., Saravanan, P., $2009 \mathrm{~b}$. Electro-oxidation of saline wastewater from tannery and reuse of recovered salt. Journal of the American Leather Chemists Association, 104(11), 384-391.

Yu, S. X., 1999. A review of the alternative technologies for raw hides and skins preservation. China Leather, 28(17), 23-25.

Zengin, A. C. A., Colak, S. M., Zengin, G., Kilic, E., 2014. Eco-friendly soaking process using tannic acid as an alternative bactericide. Archives of Environmental Protection, 40(1), 3-12. 